\title{
Soma-Eynez Fayının Düş̧en Bloğunda (670-Topuğu) Yeralan Bir Açık Ocak Kömür Madenindeki Gözlenen Devrilme Yenilmelerinin İncelenmesi
}

Investigation of Toppling Failures in an Open Pit Coal Mine Located in the Foot Wall of Eynez

\author{
Fault-Soma (670-Pillar)
}

\author{
Batuhan TERLI' ${ }^{1} \mathbb{D}$, Enes KALHAN ${ }^{1} \mathbb{D}$, M. Yalçın KOCA ${ }^{2 *} \mathbb{D}$ \\ ${ }^{1}$ Dokuz Eylül Üniversitesi, Fen Bilimleri Enstitüsü, Uygulamalı Jeoloji Anabilim Dall, 35160, İzmir \\ ${ }^{2}$ Dokuz Eylül Üniversitesi, Mühendislik Fakültesi, Jeoloji Mühendisliği Bölümü, 35160, İzmir
}

\section{ÖZ}

670 topuğu, Eynez fayının deformasyon zonundan hem düşen, yuvarlanan kaya bloklarını tutmak hem de fay zonu boyunca oluşacak heyelanlara ait malzemelerin kömür üretim sahasına gelmesini engelleyecek jeolojik bir bariyerdir. Soma-Eynez fayının düşen bloğunu oluşturur ve Neojen yaşlı marnlardan oluşur. 670 topuğu şevlerinde gözlenen kaya devrilme yenilmeleri açık ocakta kömür üretimine yönelik kazı çalışmalarının güvenliğini tehdit etmiştir. Söz konusu kütle hareketlerinin sonucunda devrilen, düşen ve yuvarlanan kaya parçalarının farklı şev yüksekliklerinde maksimum yuvarlanma mesafeleri bilgisayar yazılımı kullanılarak belirlenmiştir. Farklı şev yükseklikleri için hesaplanan yuvarlanma mesafeleri dikkate alınarak açık ocak kömür işletmesine ait proje kazı sınırı belirlenmiştir. Bu çalışmada, 670-topuğunda gözlenen devrilme yenilmeleri stereografik projeksiyon ve farklı bilgisayar programları kullanılarak sırasıyla hem kinematik hem de sayısal olarak incelenmiştir. Aynı şev geometrileri için farklı yazılımlardan elde edilen güvenlik faktörleri karşılaştırılmış, devrilme yenilmelerine neden olan çatlak yüzeylerine ait sürtünme açısı ve kohezyon değerlerinin güvenlik faktörü üzerindeki etkileri araştırılmıştır. Buna ek olarak, devrilmeye neden olan çatlaklar üzerinde tesis edilmiş 20 adet deformasyon ölçüm noktasından elde edilen çatlak açıklığı ilerleme hızlarının zamana bağlı değişimleri incelenmiştir. Açılma hızının en yüksek olduğu alanlarla topuğun şevinde devrilme yenilmesinin gözlendiği alanlar ilişkilendirilmiştir.

Anahtar Kelimeler: Devrilme Duraysızlığı, Kaya Şev Stabilitesi, Stereografik Projeksiyon, Çatlak Açıklığı Artış Hızı, Proje Kazı Sınırı

\begin{abstract}
670 pillar is a geological barrier that will trap the rock blocks falling and rolling from the deformation zone of the Eynez fault as well as to prevent the materials belonging to the landslides to be formed along the fault zone from reaching the coal production area. It forms the foot wall of Soma-Eynez fault and consists of Neogene aged marls. The toppling failures observed in the 670-pillar's slopes threatened the safety of excavation works for coal production in the open pit. The maximum runout distances of rock fragments that had toppled, fallen and rolled at different slope heights as a result of the mentioned mass movements were determined using computer softwares. The project excavation limit for the open pit coal mine was determined by considering the runout distances calculated for different slope heights. In this work, toppling failures observed in the 670-pillar's slopes were investigated both
\end{abstract}


Terli, Kalhan, Koca

kinematically and numerically, using stereographic projection and different computer softwares, respectively. Safety factors obtained from different softwares for the same slope geometries were compared and the effect of friction angle $(\phi)$ and cohesion (c) values of the joint surfaces on safety factor that cause toppling failures were investigated. In addition, the time-dependent changes of joint aperture increase rate obtained from 20-deformation measurement points installed on the cracks causing toppling failures were investigated. The areas where the joint aperture increase rate is highest and the areas where the toppling failure is observed in the pillar's slope were associated.

Keywords: Toppling Failure, Rock Slope Stability, Stereographic Projection, Joint Aperture Increment Rate, Project Excavation Boundary

\section{GíRiş}

Soma-Eynez açık ocak kömür işletmesinde, 2014 yılında yaklaşık 15 yıl olarak planlanan ve 133.462.856 $\mathrm{m}^{3}$ dekapaja karş111k 15.347.412 ton linyit kömürü üretim kazısı projelendirilmiştir. Kömür üretimi yapılması planlanan sahanın doğusunda $670 \mathrm{~m}$ seviyesinde yeralan düzlük üzerinde (670-topuğu) gerilme çatlakları ve 670-topuğundan itibaren $570 \mathrm{~m}$ seviyesine kadar olan topuğa ait basamak şevlerinde de kaya devrilme yenilmesi şeklinde kütle hareketlerinin neden olduğu şev bozulmaları gözlenmiştir (Şekil 1). Bu çalışma üç konu üzerine temellendirilmiştir; i) 670 topuğunun açık ocağa bakan şevinde gözlenen devrilme türü kütle hareketlerinin (block toppling instabilities) farklı yazılımlar kullanılarak incelenmesi ve sonuçlarının mühendislik jeolojisi açısından değerlendirilmesi, ii) Şev stabilitesinin yanısıra analizlerin diğer bir amac1; kohezyon ve sürtünme açısının güvenlik faktörü üzerindeki etkisinin belirlenmesi, farklı kohezyon (c) ve sürtünme açısı ( $\phi$ ) değerleri için, şev yükseklikliği değişiminin güvenlik faktörü üzerindeki etkilerinin farklı bilgisayar yazılımları kullanılarak incelenmesi, iii) Eynez açık ocak işletmesinde kütle hareketi gözlenen veya potansiyele sahip arazi kesimi için güvenli çalışma alanının sınırlarını belirleyecek olan "proje kazı sınırının" çizilmesidir. Farklı şev yükseklikleri için bilgisayar yazılımı kullanılarak belirlenen maksimum yuvarlanma noktaları, harita üzerinde birleştirilerek proje kazı sınırı oluşturulmuştur. $\mathrm{Bu}$ sınırın batısında kalan sahada, düşen ve yuvarlanan kaya bloklarından etkilenmeden kömür üretimi güvenli şekilde yapılabilecektir. $\mathrm{Bu}$ çalışmada, devrilme yenilmesi hem kinematik hem de nümerik olarak incelenmiş ve kütle hareketinin oluşum mekanizması mühendislik jeolojisi açısından değerlendirilmiştir. 670-topuğu (yüzey alanı; $\left.85 \times 103 \mathrm{~m}^{2}\right), \mathrm{K}-\mathrm{G}$ uzanımlı Eynez fayı ile bu faya paralel gelişmiş, topuğu batıdan sınırlayan ikinci bir fay arasında yer almaktadır (Şekil 1). Her iki fay da topuğun kuzeyinden geçen, KDD - GBB uzanımlı üçüncü normal bir fayla kesilmiştir (Şekil 1). Böylece, topuk doğudan, batıdan ve kuzeyden faylarla sınırlanmıştır. İnceleme alanında, doğudan batıya doğru sirasıyla Eynez fayı, yüzeyi düzlük şeklinde olan ve fayın düşen bloğunu teşkil eden 670-topuğu, topuğun batı kenarından ve şev tabanından geçen, Eynez fayına paralel gelişmiş, $130 \mathrm{~m}$ aralıklı iki normal fay ve daha sonra ikinci emniyet topuğu olarak bırakılan ikinci düzlük alan $\left(\leq 5^{\circ}\right)$ (yer almaktadır (Şekil 1). Eynez fayına paralel uzanmış $130 \mathrm{~m}$ aralıklı iki tali fay arasında yer alan yüksek eğimli şevler (sarı renkli alanlar) bu çalışmada incelenen devrilme yenilmelerinin gözlendiği alanlardır. İkinci tali faydan, sınırı bu çalışmada belirlenmiş "proje kazı sınırına" kadar olan alan, ikinci emniyet topuğu olarak birakılması önerilen alandır (yeşil boyalı alanlar). 670 topuğu Eynez fayının, ikinci emniyet topuğu ise, ikinci tali fayın düşen blokları üzerinde 
yer almaktadır (Şekil 1). Emniyet topuklarını oluşturan her iki fay da yüksek açılı normal fay özelliğindedir. 670 topuğu, Eynez fayının deformasyon zonundan düşen, devrilen ve yuvarlanan kaya parçalarını tutan birinci emniyet topuğu niteliğindedir (Şekil 1). Birinci ve ikinci emniyet topukları arasında yeralan şevlerde gözlenen kütle hareketlerinin incelenmesinin yanı sıra, söz konusu şevlerden devrilen, düşen ve yuvarlanan kaya bloklarının maksimum yuvarlanma mesafelerinin belirlenmesi de bu çalışmanın araştırma konularındandır.

$\mathrm{Bu}$ çalışmada, devrilmeye neden olan çatlak yüzeyleri üzerinde yapılan makaslama deney sonuçlarından elde edilen sürtünme açısı ve kohezyonun çok sınırlı değerleri için $(\leq 60 \mathrm{kPa})$ devrilme analizleri yapılmıştır. Şev stabilitesinin yanı sıra, analizlerin diğer bir amac1; kohezyon ve sürtünme açısının güvenlik faktörü üzerindeki etkisinin belirlenmesine yöneliktir. Buna ek olarak, farklı kohezyon (c) ve sürtünme açısı (ф) değerleri için, şev yükseklikliği değişiminin güvenlik faktörü (FoS ve SRF) üzerindeki etkileri de RocTopple V.2.0 (Rocscience Inc, 2020) ve Phase $^{2}$ v.7.0 (Rocscience Inc, 2008) bilgisayar yazılımları kullanılarak incelenmiştir.

Devrilme süreksizlik kontrollü bir kaya yenilme türüdür ve kaya düşmesi kaynak zonlarında gelişir. Hoek (1974)'e göre devrilme yenilmesi, blok tabanıyla ilişkili olan blok ağırlık vektörünün konumuna bağlıdır ve blok ağırlık vektörü blok tabanının dişına düşerse, şevde devrilme yenilmesi potansiyeli doğmaktadır. Yüksek eğimli şevlerde eğim yönü yamaç içine, eğim açısı dik ve dike yakın, şev yüzeyine paralel doğrultudaki süreksizlikler sıklıkla devrilme yenilmesine neden olur. Süreksizliklerin eğim açısı arttıkça, kaya şevlerinde devrilme tehlikesi de artar (Wyllie, 1989; Bobet, 1999; Koca ve Kincal, 2004; Wyllie ve Mah, 2004; Brideau ve Stead, 2009). Goodman ve Bray (1976) arazide karşılaşılan değişik devrilme yenilmeleri tanımlamıştır. Bunlar, i) Blok devrilmesi ii) Bükülme devrilmesi (Fleksür devrilmesi), iii) Blok-bükülme devrilmesi (Blok-fleksür devrilmesi) ve iv) Farklı kaya birimlerinin farklı ayrışma derecelerinde olması, farklı jeolojik yapıların varlığına bağlı olarak gelişen ikincil devrilme tipleridir. 670 topuğunun batı şevinde gözlenen devrilme yenilmeleri, birinci gruba girmektedir.

Eynez açık ocak kömür sahasında, blok oluşumuna neden olan çatlaklar üzerine tesis edilmiş 20 adet deformasyon ölçüm noktasında, 8 Eylül 2015 ile 02 Haziran 2016 tarihleri arasında, dört farklı zamanda yapılan ölçümlerden elde edilen çatlak açıklığı artış hızı değerlerinin zamana bağlı değişimleri incelenmiştir. Buna ek olarak, çatlak açıklığındaki hareket miktarı ve yönü belirlenmiş ve de ölçüm noktalarındaki hareket miktarları dikkate alınarak belli aralıklarla konturlanmıştır. Böylece, 670 topuğu üzerinde en çok yer değiştirme hareketinin gözlendiği alanlar belirlenmiştir. Kontur yönelimleri/uzanımları ile çatlak takımlarının doğrultu ve eğim yönleri ilişkilendirilmiştir. Çatlak açıklık miktarının ve açılma hızının en yüksek olduğu alanlarla, 670 topuğunun şevinde devrilme yenilmesinin gözlendiği alanlar ilişkilendirilmiştir. 


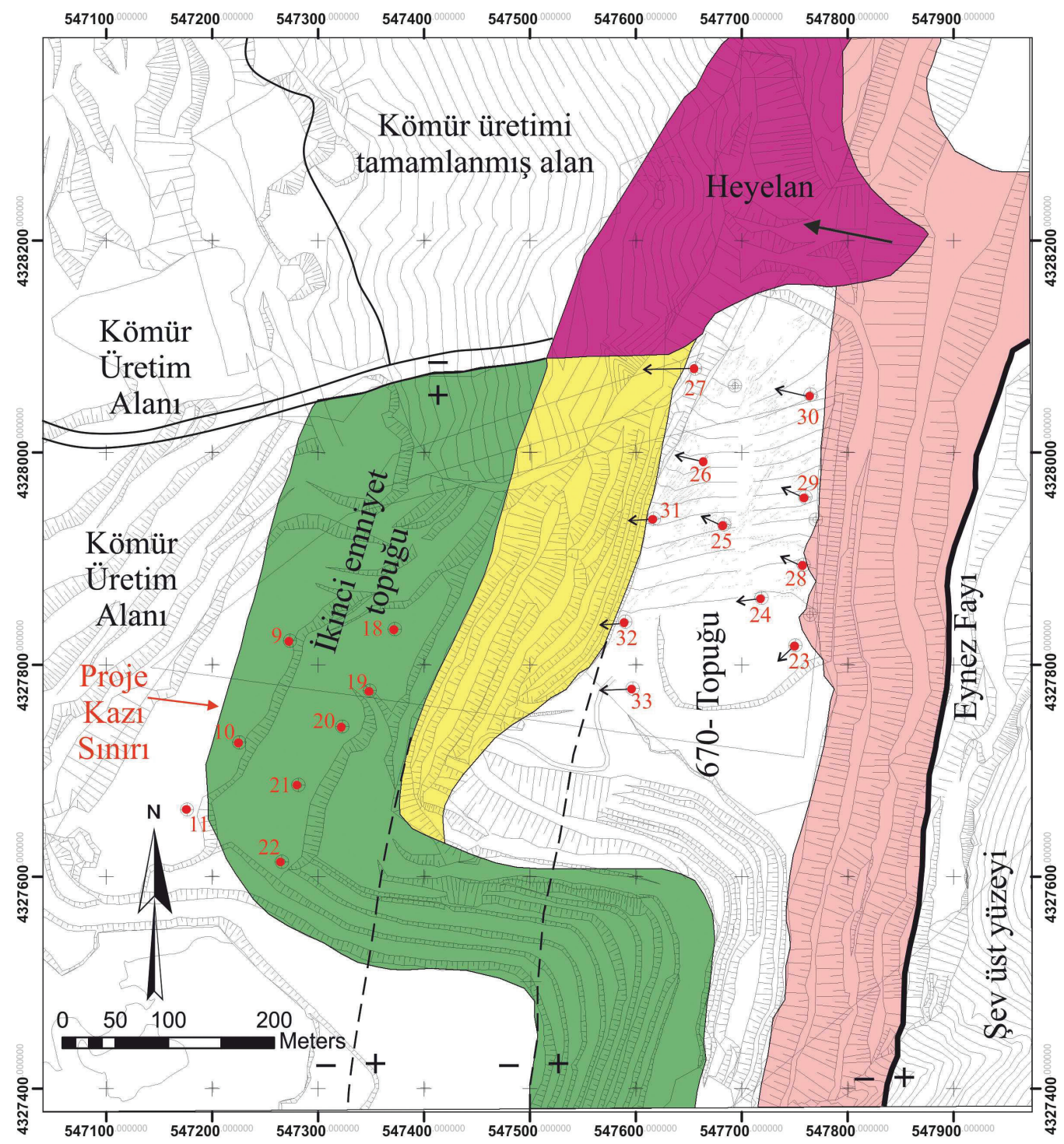

\section{$\underline{\text { AÇIKLAMA }}$}

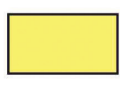

Devrilme yenilmelerinin gözlemlendiği alan

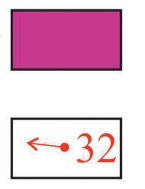

Heyelan sahası

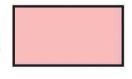

Eynez fayının

deformasyon zonu

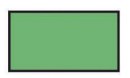

İkinci emniyet topuğu

Deformasyon

ölçüm yeri

Şekil 1. Eynez fayı deformasyon zonu, 670 topuğu, kaya devrilme yenilmesi etki alanı ve kazı emniyetinin sağlanması için kömür üretim faaliyetlerinde bulunulmaması gereken tampon bölge, ikinci emniyet topuğu.

Figure 1. Deformation zone of the Eynez fault, 670-pillar, toppling failure impact area and the buffer zone where the coal production activities should not be carried out to ensure the excavation safety, second safety-pillar. 


\section{YÖNTEMLER}

Devrilme yenilmelerinin kinematik incelemesinde stereografik projeksiyon tekniği yaygın olarak kullanılmaktadır (Hoek ve Bray, 1974; Goodman ve Bray, 1976; Matterson, 1988; Norrish ve Wyllie, 1996; Yoon vd., 2002; Kıncal ve Koca, 2009). Bu çalışmada, devrilme yenilmelerinin kinematik incelenmesi veya kaya şevinde devrilme potansiyelinin olupolmadığı Hoek ve Bray (1974) ve Norrish ve Wyllie (1996) tarafından önerilen yöntemler kullanılarak gerçekleştirilmiştir. Eynez 670-topuğundan 94 adet süreksizlik (tabaka ve çatlak) ölçüsü alınarak süreksizlik takımlarına ait kutup yoğunlaşma noktaları bulunmuştur. $\mathrm{Bu}$ noktalara ait büyük dairelerin konumuyla, şev düzleminin büyük dairesinin konumu (52/280) karşılaştırılmıştır. Şeve ait devrilme zarfının (toppling envelope) içine hangi kutup noktasının düştüğü belirlenmiştir. Zarfın içine düşen kutup noktasına ait süreksizlikler kinematik olarak devrilme potansiyeline sahiptir. Devrilme zarfinın çizilmesinde, Hoek ve Bray (1974) ve Norrish ve Wyllie (1996) tarafindan önerilen yöntemler birbirlerinden farklıdır. Birinci araştırmacıya göre $\phi$-aç1s1, stereografik projeksiyon netinin dışından içine doğru, ikinci araştırıcıya göre ise, şev düzleminin büyük dairesinden itibaren netin dışına doğru alınmaktadır. $\mathrm{Bu}$ çalışma kapsamında, 670 topuğu ve şevinde gerçekleştirilen detay süreksizlik ölçümleri (süreksizlik aralığ 1 , devamlılığ 1 gibi) ISRM (2007) tarafindan önerildiği üzere hat etüdü (scan-line) yöntemiyle gerçekleştirilmiştir.

Devrilme yenilmesine neden olan çatlak yüzeylerinde gerçekleştirilen makaslama deney sonuçlarından elde edilen rezidüel (kalıcı) sürtünme açısı değeri $\left(\phi_{\mathrm{r}}\right)$ devrilme zarfının çizilmesinde kullanılmıştır. 670 topuğu Eynez fayının düşen bloğunu oluşturur. $\mathrm{Bu}$ nedenle, kırıklı yapılarıyla marnlar yoğun tektoniğin izlerini taşır. Kinematik olarak devrilme potansiyeline sahip süreksizlikler, yüzey sürtünme açısı ve çatlak yüzeylerine ait direnç parametreleri belirlendikten sonra nümerik analizlere başlanmıştır. RocTopple v.2.0 ve Phase $^{2}$ v.7.0 bilgisayar yazılımları devrilme analizlerinde kullanılmıştır. RocTopple v.2.0 kaya şevlerinin devrilme analizlerinde ve destek tasarımında kullanılan ve limit denge ilkesiyle çalışan bir yazılımdır. Program blok devrilmesi ve bükülme devrilmesi olmak üzere iki farklı türdeki analizleri yapabilmektedir. Analizlerde şev geometrisiyle birlikte devrilmeye neden olan süreksizlikler, kaya bloklarını kesen şev dışına eğimli süreksizlikler, süreksizlik aralığı, süreksizlik yüzeylerine ait sürtünme açısı ve kohezyon değerleri dikkate alınmaktadır.

Phase $^{2}$ mühendislik uygulamalarında kullanılan 2D sonlu elemanlar (FEM) yazılımıdır. Analizi yapılacak kaya şevinin geometrisi ve şevi oluşturan malzemelerin sınırları ve özellikleri $(\gamma$, v, $\mathrm{E}_{\mathrm{i}}, \mathrm{c}, \phi$ vb.) programa tanitılır. Kayaç kütlesi içerisindeki süreksizlik setleri model içerisine işlenir. Buna ek olarak, yayılı yükler, yeraltı su seviyesi ve deprem durumu gibi parametreler modele eklenebilmektedir. Analizlerin gerçekleştirilmesinde Mohr-Coulomb yenilme ölçütü dikkate alınmıştır. Süreksizliklerle ilgili olarak programa, devrilmeye neden olan çatlak yüzeylerinin ve sağlam kayaya ait pik ve rezidüel direnç parametreleri $\left(\varnothing_{\mathrm{r}_{\mathrm{r}}} \mathrm{c}_{\mathrm{r}}, \varnothing_{\mathrm{p}}\right.$ ve $\left.\mathrm{c}_{\mathrm{p}}\right)$, yamaç dışına eğimli, şevi kesen tabaka yüzeylerinin kohezyon ve içsel sürtünme açısı değerlerinin yanısıra devrilme yenilmesine neden olan çatlaklara ait rijitlik değerleri de programa girilmektedir. Kayaç kütlesi içerisindeki gerilme dağılımları, yer değiştirmeler ve şevin güvenlik faktörü (SRF) programdan elde edilmektedir. $\mathrm{k}_{\mathrm{n}}$ (normal stiffness) ve $\mathrm{k}_{\mathrm{s}}$ (shear stiffness) ile tanımlanan çatlakların deformabilitesinin (normal ve kesme 
rijitliği değerleri), 10 kat kadar farklı olmaması önceki çalışmalarda belirtilmiştir (Bandis vd., 1983; Son vd., 2004; Nassir vd., 2013). Dolgusuz çatlaklarda $\mathrm{k}_{\mathrm{s}}$ değerleri $>100 \mathrm{MPa} / \mathrm{m}$ mertebesindedir. $\mathrm{k}_{\mathrm{s}}$; makaslama gerilmeleri altında malzemenin deformasyona direncidir ve makaslama gerilmesi - makaslama yer değiştirmesi grafiğinin eğiminden elde olunur $\left(\mathrm{k}_{\mathrm{s}}=\frac{\text { Makaslama gerilmesi }}{\text { Makaslama yer değiştirmesi }}\right)$. . Itasca (2000)'de çatlakların kil dolgulu olması durumunda, kesme rijitliği için değerlerin $10-100 \mathrm{MPa} / \mathrm{m}$ arasında olması önerilmiştir. $\mathrm{Bu}$ çalışmada çatlaklara ait rijitlik değerinin hesaplanmasında Barton (1972) tarafından önerilen eşitlikler kullanılmıştır; $\quad \mathrm{k}_{\mathrm{n}}=\frac{E_{i} \times E_{M}}{s\left(E_{i}-E_{M}\right)}$ ve $\mathrm{k}_{\mathrm{s}}=\frac{G_{i} \times G_{M}}{s\left(G_{i}-G_{M}\right)}$ burada $s$; devrilmeye neden olan çatlaklara ait süreksizlik aralığ 1 değeridir. $\mathrm{E}_{\mathrm{i}}$ ve $\mathrm{E}_{\mathrm{M}}$ ise, sırasıyla kaya malzemesi ve kaya kütlesine ait elastisite modülü değerleridir. $G_{i}$ ve $G_{M}$; kaya malzemesi ve kütlesine ait kayma modülü değerleridir. Burada $G_{i}$ değeri, $\frac{E_{i}}{2(1+\vartheta)}$ eşitliği yardımıyla belirlenir. Normal ve kesme rijitliği değerleri $\mathrm{M}_{2}$-marnları için hesaplandıktan sonra Phase ${ }^{2}$ yazılımı kullanılarak farklı şev yükseklikleri için gerilme azaltma faktörü (SRF) değerleri hesaplanmıştır.

670 topuğunun batıya bakan şevlerinden devrilen, düşen ve yuvarlanan kaya bloklarının maksimum yuvarlanma noktalarının ve sıçrama yüksekliklerinin belirlenebilmesi için çalışmada RocFall v.4.0 (Rocscience Inc, 2004) bilgisayar yazılımı kullanılmıştır. Kaya bloklarının maksimum yuvarlanma noktaları farklı şev yükseklikleri için $(74,84,94$ ve 110 m) hesaplanmıştır (670-topuğunun şevi boyunca şev yükseklikleri kuzeyden güneye doğru azalarak değişmektedir). Harita üzerine aktarılan maksimum yuvarlanma noktaları birleştirilerek
Eynez kömür sahası için proje kazı sınırı çizilmiştir (Şekil 1). RocFall programı kaya düşmesi riski altında olan yamaçların stabilite değerlendirmesine yardımc1 olan 2-boyutlu istatistiksel analiz programidir. Analizler yap1lırken, şev geometrisi, şevi oluşturan kaya malzemelerinin özellikleri dikkate alınır. Oluşturulan şev geometrisinde kaya düşmesi kaynak noktası belirlenerek, düşmesi muhtemel blokların özellikleri, hareketin gerçekleştiği yüzeylere ait sönümleme katsayıları ve diğer parametreler programa girilmektedir. Oluşturulan model ve programa girilen parametreler yardımıyla düşen kayanın sıçrama yükssekliği, kinetik enerjisi ve maksimum yuvarlanma noktası programdan elde edilmektedir.

670 topuğunun üzerinde 11, ikinci emniyet topuğunun üzerinde de 9 adet olmak üzere toplam 20 deformasyon ölçüm noktasında, farklı zamanlarda çatlak açıklıkları ve hareket yönleri ölçülmüştür. Ölçümlerde Leica marka total station cihazı kullanılmıştır. Çatlak üzerine boyu $100 \mathrm{~cm}$ olan bir demir çubuk çakılmış ve bu çubuğun konumsal ölçümü, hareketli olmadığ 1 bilinen sabit bir poligon noktasından farklı zaman aralıklarında gerçekleştirilmiştir. Cihazın hata payı $\pm 2 \mathrm{~mm}$ olarak tanımlansa da tekrarlı ölçümlerde cihazın kurulması ve personel kaynaklı hataları en aza indirmek için $2 \mathrm{~cm}$ 'nin altında hareket miktarları değerlendirmeye alınmamıştır. Buna ek olarak, 2 cm'nin üzerinde ve şev hareketi yönünde olmayan hareketler de değerlendirme dışında tutulmuştur.

\section{JEOLOJI}

İnceleme alanında Miyosen ve Pliyosen yaşlı tortul kayaçların yanısıra Kuvaterner yaşlı yamaç molozları ve kömür üretimine yönelik kazılar nedeniyle hareket etmiş heyelan malzemeleri yer alır. Neojen yaşlı tortul istif, Mesozoyik yaşlı, 
masif, kalın katmanlı rekristalize kireçtaşları üzerine uyumsuz olarak gelmektedir (Şekil 2). Stratigrafik kesitte görülebileceği üzere, işletilen ana kömür damarının $\left(\mathrm{KM}_{2}\right)$ üzerinde orta katmanlı, krem renkli marnlar (örtü kayac1), altında ise "taban kili" olarak adlandırılan ince katmanlı, yeşilimsi gri renkli çamurtaşları yer almaktadır (Şekil 2). Jeolojik birimlerin dokanak ilişkileri ve kalınlıkları stratigrafik kolon kesitte ayrıntılı olarak verilmiştir.

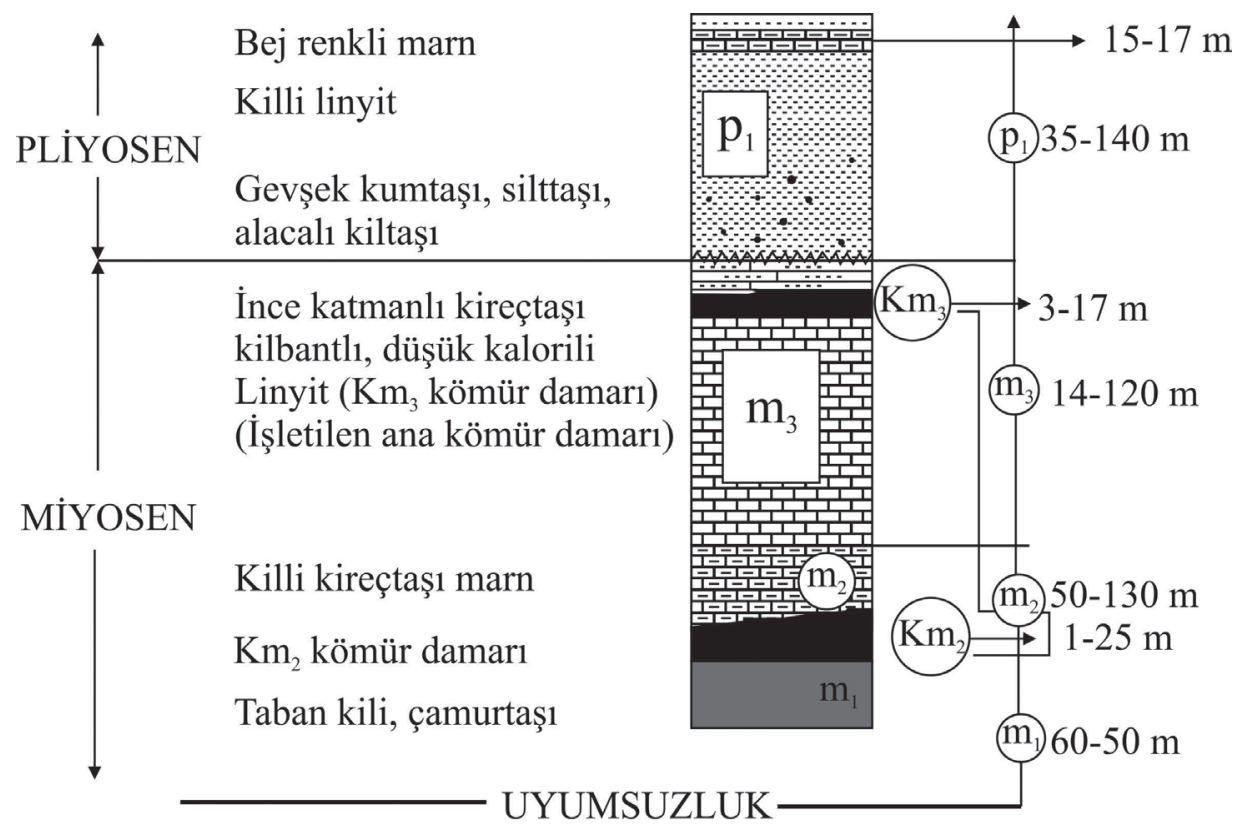

Mesozoyik yaşı, masif, kalın katmanlı rekristalize kireçtaşı (taban kayası) adet tek eksenli sıkışma dayanımı deneyinden ikisinde deformasyon kontrollü olarak deneyler gerçekleştirilmiştir. Deneylerden elde edilen gerilme - deformasyon eğrileri Şekil 3'te verilmiştir. Kaya malzemesine ait elastisite modülü değerleri $\left(E_{\mathrm{i}}\right), 1$ ve 2 nolu karot örnekleri için grafiklerden 11.1 ve $10.0 \mathrm{GPa}$ olarak hesaplanmıştır. Kaya malzemeleri için tipik gerilme-deformasyon eğrileri dikkate alındığında, marnların elastik-plastik bir

Şekil 2. İnceleme alanının stratigrafik kolon kesiti.

Figure 2. Stratigraphic columnar section of the study area.

\section{MÜHENDISLLIK JEOLOJISI}

\section{Laboratuvar Deneyleri}

Marnlara ait kaya bloklarından elde edilen karot örnekleri $(\mathrm{n}=9)$ üzerinde kayacın bazı fiziksel ve mekanik özelliklerini belirlemek üzere laboratuvar deneyleri yapılmıştır (Çizelge 1). Deneyler ISRM (2007) tarafından önerilen yöntemler dikkate alınarak yapılmıştır. Dokuz malzeme davranışı gösterdiği anlaş1lır. IAEG (Anon, 1979a)'a göre $M_{2}$ marnları “yüksek

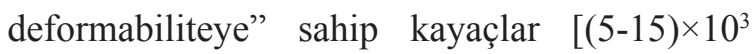
$\mathrm{MPa}$ ] sınıfına girmektedir. Tek eksenli sıkışma dayanımı, ve sağlam kayanın elastisite modülü, $\mathrm{E}_{\mathrm{i}}$ değerleri dikkate alındığında, Deere ve Miller (1966)'a göre $M_{2}$ - marnları"düşük dirençli, orta modül oranına" sahip kayaçlardır. 
Terli, Kalhan, Koca

Çizelge 1. Marnların bazı fiziksel ve mekanik özellikleri.

Table 1. Some physical and mechanical properties of the marls.

\begin{tabular}{|c|c|c|}
\hline Deneyler & Deney sonuçları & Ekipman özellikleri \\
\hline Doğal birim ağırlık $\left(\mathrm{t} / \mathrm{m}^{3}\right), \mathrm{n}=9$ & $2.30 \pm 0.035$ & - \\
\hline Görünür porozite $(\% n), n=9$ & $5.50 \pm 0.261$ & - \\
\hline $\begin{array}{l}\text { Tek eksenli sıkışma dayanımı }\left(\mathrm{kgf} / \mathrm{cm}^{2}\right) \\
\mathrm{n}=9\end{array}$ & $307.0 \pm 51.2$ & ELE ADD 2000, Y.H: 2 kN/sn, D.H: $10^{-5} \mathrm{sn}^{-1}$ \\
\hline $\begin{array}{l}\text { Nokta yük dayanım indeksi }\left(\mathrm{kgf} / \mathrm{cm}^{2}\right) \\
\mathrm{n}=8\end{array}$ & $30.4 \pm 5.26$ & Y.H: 200N/sn, ISRM (2007) \\
\hline $\begin{array}{llll}\text { İndirek } & \text { çekme dayanımı } \quad\left(\mathrm{kgf} / \mathrm{cm}^{2}\right) \\
\mathrm{n}=10\end{array}$ & $21.1 \pm 2.47$ & - \\
\hline $\begin{array}{l}\text { Kayada direk makaslama direnci tayini, } \\
\mathrm{n}=12\end{array}$ & $\begin{array}{l}\tau_{\mathrm{p}}=0.26+\sigma 0.90 \mathrm{ve} \\
\tau_{\mathrm{r}}=0.50+\sigma 0.65\end{array}$ & $\begin{array}{l}\text { ELE, code: } 771040 / 10-11, \text { mak. örnek } \\
\text { büyüklügüü: } 115125 \mathrm{~mm} \text {, mak. karot örneği çapı: } \\
102 \mathrm{~mm}, 10 \mathrm{~mm} / 100 \mathrm{~kg} \text {. ISRM (2007) }\end{array}$ \\
\hline $\begin{array}{l}\text { Kil dolgulu marn tabaka yüzeyleri için } \\
\text { makaslama direnci tayini, n: } 6\end{array}$ & $\begin{array}{l}\tau=0.016+\sigma 0.445 \\
\phi=24^{\circ}, \mathrm{c}=16 \mathrm{kPa}\end{array}$ & $\begin{array}{l}\text { Wykham Farrance, Deformasyon kontrollü } \\
\text { zemin makaslama cihaz1, } 5 \mathrm{kN} / 60 \mathrm{~mm} \text {, örnek: } 66 \\
\mathrm{~cm}^{2} \text {, Standart: TS 1900-2 }\end{array}$ \\
\hline
\end{tabular}

Açıklama: n: Deney sayısı, Y.H: Yükleme hızı, D.H: Uygulanan deformasyon hızı

Blok boyutu ve yüzey koşulları gibi süreksizlik özelliklerinin kaya kütlesi dayanımındaki azaltıcı etkisini dikkate alarak Marinos ve Hoek (2001) tarafından oluşturulan tablolardan $\mathrm{M}_{2}$ - marnlarının jeolojik dayanım indeksi (GSI) 52 olarak belirlenmiştir. $\mathrm{E}_{\mathrm{i}}=10^{4}$ $\mathrm{MPa}$ (Şekil 3) ve GSI = 52 için $\mathrm{M}_{2}$ - marnlarının kayaç kütlesine ait elastisite modülü değeri Hoek ve Diederichs (2006) tarafından önerilen eşitliğe göre; $\mathrm{E}_{\mathrm{M}}=1219.60 \mathrm{MPa}^{\prime}$ dır. Bu değerlendirmede patlatma etki faktörü $\mathrm{D}=0.7$ olarak dikkate alınmıştır. Bu veriler ışığında, devrilmeye neden olan çatlaklara ait rijitlik değeri, $\mathrm{k}_{\mathrm{n}}=1410 \mathrm{MPa} / \mathrm{m}$ olarak hesaplanmıştır. $\mathrm{G}_{\mathrm{i}}=\frac{E_{i}}{2(1+\vartheta)}$ eşitliğinden $\mathrm{G}_{\mathrm{i}}=3846.15 \mathrm{MPa}$ ve $\mathrm{G}_{\mathrm{M}}=469.08 \mathrm{MPa}$ olarak elde edilir. Sağlam kaya ve kaya kütlesine ait kayma modülü (shear modulus) değerleri kullanılarak kesme rijitliği değeri $\mathrm{k}_{\mathrm{s}}=542.4$ $\mathrm{MPa} / \mathrm{m}$ olarak hesaplanmıştır. $\mathrm{Bu}$ durumda, $\left(k_{n} / k_{s}\right)$ oran1 2.6 olarak elde edilmiştir. SRF değerlerinin hesaplanmasında, normal ve kesme rijitliği değerleri olarak bilgisayar programına $\left(\right.$ Phase $^{2}$ ) yukarıda hesaplanan değerler girilmiştir.

Marn tabaka yüzeyleri, sağlam kaya ve çatlak yüzeylerinin makaslama direnci parametrelerini belirlemek üzere toplam 18 adet deney yapılmıştır (Çizelge 1). 18 deneyden 6's1 laboratuvarda marnların tabaka yüzeylerinin kesme dirençlerini belirlemek üzere yapılmıştır. $\mathrm{Bu}$ deneylerde seçilen tabaka yüzeyleri, ince kil dolgulu yüzeylerden oluşmaktadır. Dike yakın ve devamlılığı yüksek çatlaklardan sızan suların etkisiyle, marn tabaka yüzeylerinin arazide nemli oldukları görülmüsşür. Nemli, kil dolgulu, düz tabaka yüzeylerinin varlığı deneylerde dikkate alınmış ve düşük normal gerilme düzeylerinde bu yüzeyler boyunca yenilmeler gerçekleştirilmiştir (Şekil 4). Deneyler deformasyon kontrollü zemin makaslama cihazında yapılmıştır. Marn tabaka yüzeylerinin yenilme zarfları Şekil 6'da çizilmiştir. 


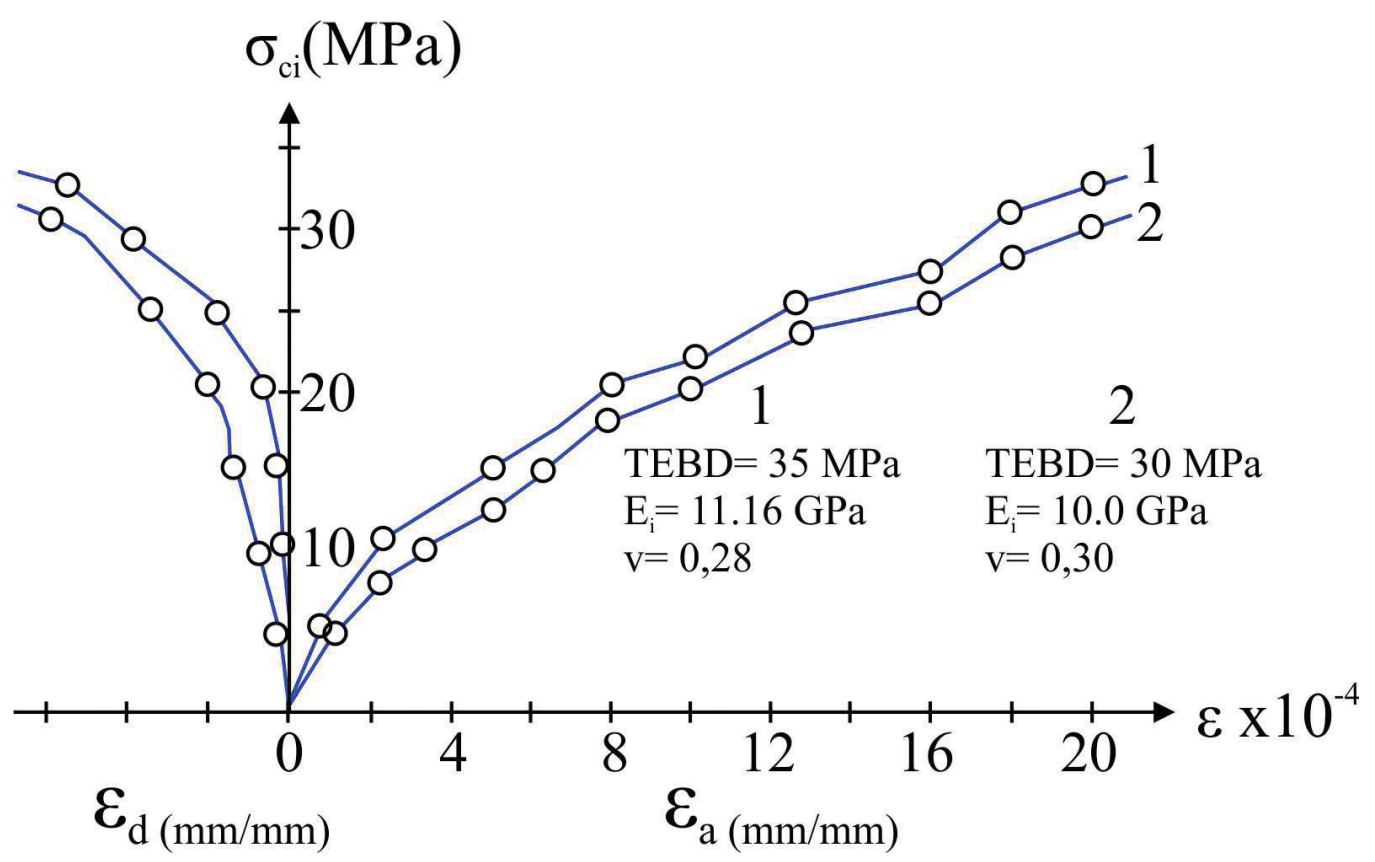

Şekil 3. $M_{2}$-marn karot örnekleri üzerinde yapılan deformasyon kontrollü tek eksenli sıkışma dayanımı deneylerinden elde edilen gerilme - deformasyon eğrileri ( $\varepsilon_{\mathrm{a}}$ ve $\varepsilon_{\mathrm{d}}$ : Eksenel ve çapsal deformasyonlar).

Figure 3. The stress-strain curves obtained from the strain controlled uniaxial compressive strength tests (UCS) conducted on the core samples of the $M_{2}$-marn ( $\left(\varepsilon_{a} a\right.$ and $\varepsilon_{d} d$ : Axial and diametral strains).

Elde edilen yenilme zarflarının eşitlikleri $\tau$ $=0.016+\sigma 0.445$ ve $\tau=0.014+\sigma 0.425$ olarak belirlenmiştir. Bu eşitliklere göre içsel sürtünme açıs $23^{\circ}-24^{\circ}$, kohezyon ise $14-16 \mathrm{kPa}$ arasında değerler almaktadır. Marn sağlam kaya örnekleri ve çatlak yüzeylerine ait pik ve rezidüel yenilme zarflarımarn tabaka yüzeylerinden farklı olarak kayada doğrudanmakaslama deney aletinde gerçekleştirilenkesmedeneyleriylebelirlenmiştir. Deney sonuçlarına göre, elde edien pik ve rezidüel yenilme zarfları Şekil 5 ve 6'da ayrı ayrı sunulmuştur. Hem süreksizlik yüzeylerine hem de sağlam kayaca ait direnç parametreleri (c ve $\phi)$ Phase $^{2}$ bilgisayar programında gerçekleştirilen devrilme analizlerinde kullanılmıştır. Marn sağlam kaya örneklerine ait doğrudan makaslama deney sonuçlarından elde edilen pik ve rezidüel yenilme zarfları sirasıyla; $\tau_{\mathrm{p}}=0.26+\sigma 0.90$ ve $\tau_{\mathrm{r}}=0.50+\sigma 0.65$ olarak elde edilmiştir (Şekil 5). RocTopple programinda sadece devrilmeye neden olan çatlak yüzeylerine ait pik ve rezidüel değerler kullanılmıştır. Çatlak yüzeylerine ait pik ve rezidüel yenilme zarfları sirasiyla $\tau_{\mathrm{p}}=$ $0.08+\sigma 0.79$ ve $\tau_{p}=0.15+\sigma 0.58$ olarak elde edilmiştir (Şekil 6). Rezidüel yenilme zarfının eşitliği dikkate alındığında, kohezyon değerinin $15 \mathrm{kPa}$ ve içsel sürtünme açısının ise $30^{\circ}$ olduğu anlaşılır. $\phi_{\mathrm{r}}=30^{\circ}$ değeri, devrilmeye neden olan çatlak yüzeylerinin sürtünme açısı olarak dikkate alınmış ve stereografik projeksiyon analizlerinde kullanılmıştır. 
Terli, Kalhan, Koca

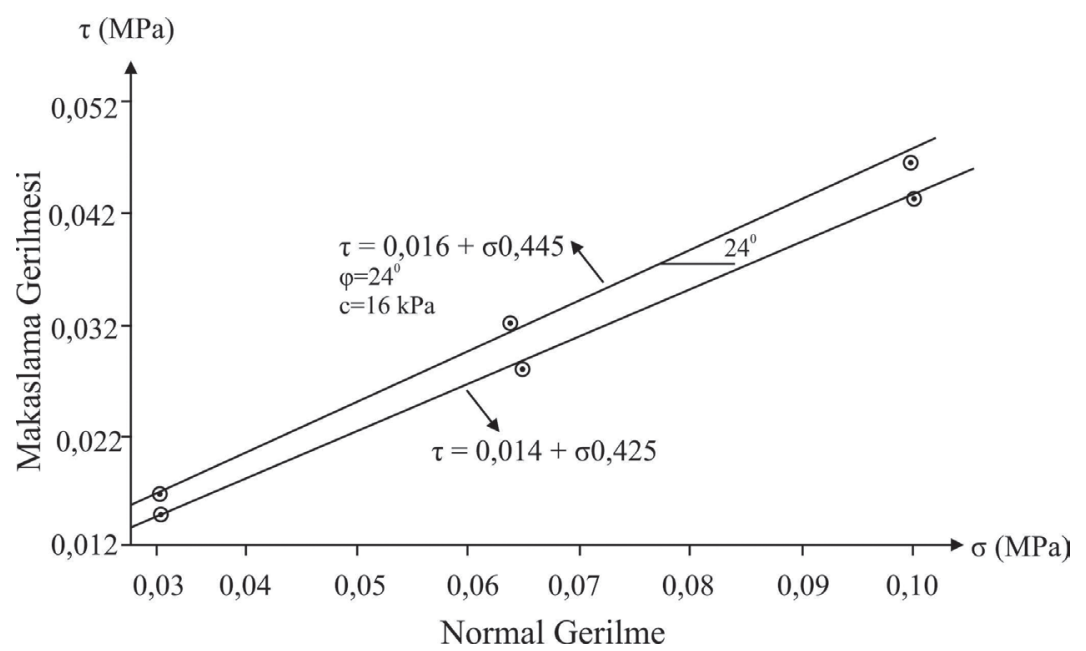

Şekil 4. İnce kil dolgulu (1-4 mm) marn tabaka yüzeylerine ait makaslama deney sonuçlarından elde edilen yenilme zarflar1.

Figure 4. Failure envelopes obtained from the shear tests for the marl layer surfaces with thin clay fill (1-4 mm).

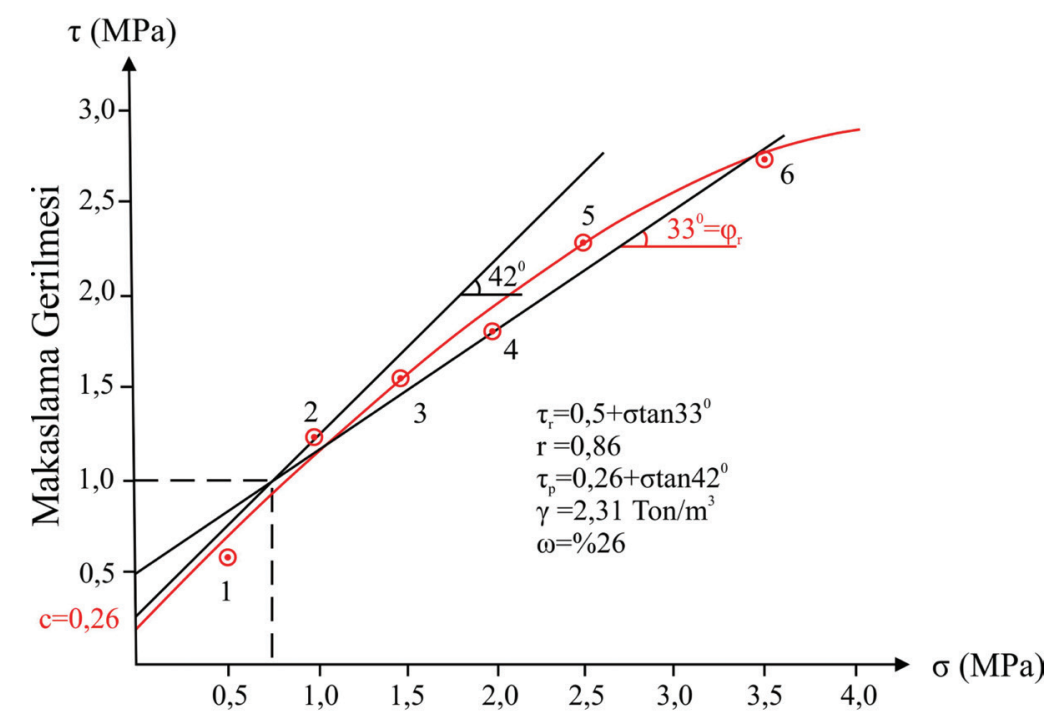

Normal Gerilme

Şekil 5. Marn sağlam kaya örneklerine ait direkt makaslama deney sonuçları.

Figure 5. Direct shear test results of the intact rock samples taken from the marl unit. 


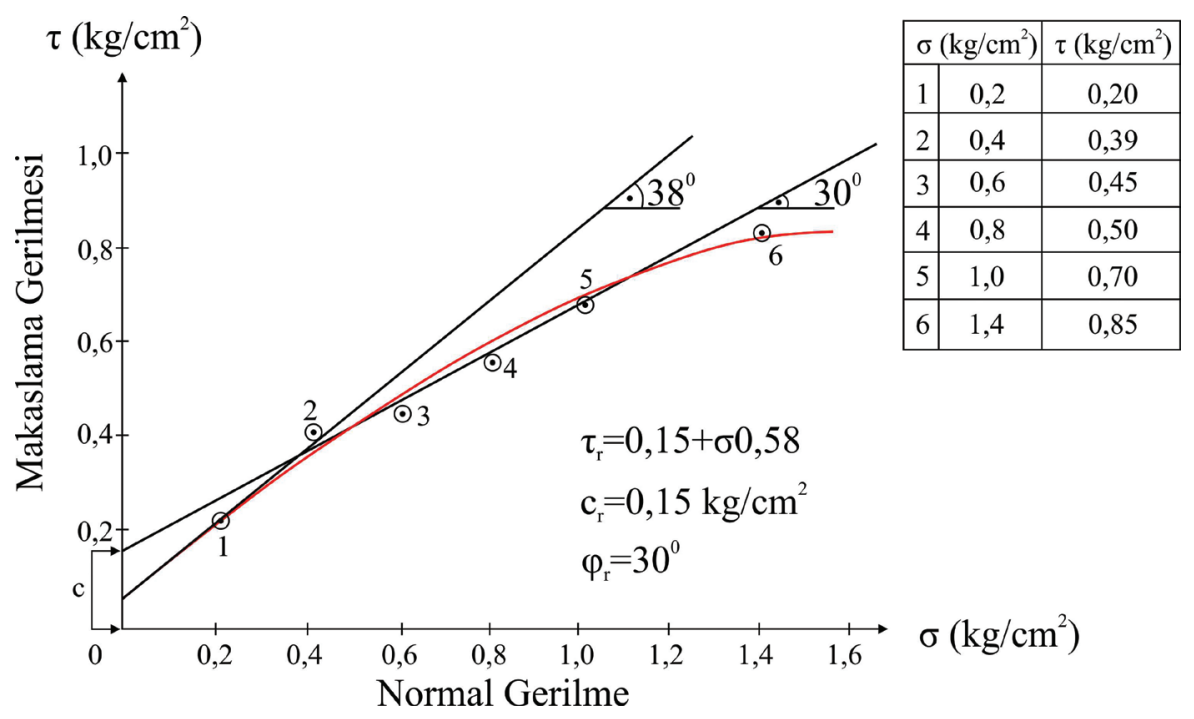

Şekil 6. Çatlak yüzeylerinin pik ve rezidüel yenilme zarfları.

Figure 6. Peak and residual failure envelopes for the joint surfaces.

\section{Topuğunda Gözlenen Blok Devrilme Yenilmesi ve Kinematiği}

Yaklaşı1k birbirine dik gelişmiş $\left(78^{\circ}\right)$ çatlaklardan ve 670 topuğuna ait şevi kesen marn tabakalarından 94 adet süreksizlik ölçüsü alınmış ve süreksizlik takımlarına ait kutup yoğunlaşma noktalarinin $\quad\left(\bar{P}_{\mathrm{I}}, \bar{P}_{\mathrm{II}}, \bar{P}_{\mathrm{III}}\right.$ ve $\left.\bar{P}_{\mathrm{T}}\right)$ belirlenmesi için bir kontur diyagramı hazırlanmıştır (Şekil 7). Kutup yoğunlaşma noktalarına ait büyük dairelerin konumları aşağıdaki gibidir; I-nolu süreksizlik seti; 70/90, II-nolu süreksizlik seti; 80 / 170, III-nolu süreksizlik seti; 90/138. Tabaka düzlemleri; 20/228. 670 topuğuna ait şevde kaya devrilmesi ve blok oluşumunu yansıtan stereogramlarise Şekil 8a ve 8b'de sunulmuştur. Şev düzleminin ve 70/90 konumlu I-nolu süreksizlik setinin eğim yönlerinin birbirinin aksi istikametinde ve doğrultuları arasındaki açı farkının $10^{\circ}$ olduğu Şekil 8a'da verilen stereogramdan görülmektedir. I-nolu süreksizlik takımını oluşturan süreksizliklerin eğim yönleri şev içine doğrudur ve devrilme türü duraysızlığ oluşturan da bu çatlaklardır (Şekil 8a ve b). Diğer taraftan, II-nolu süreksizlik takımını oluşturan ve yüksek devamlılığa sahip $(15.3 \pm 2.68 \mathrm{~m}, \mathrm{n}=10$, maksimum: $20 \mathrm{~m}$ ve minimum: $11 \mathrm{~m})$ çatlaklar şevi yaklaşık dikine kesmektedir (Şekil 9a. I-nolu çatlakların eğim yönleri şev tabanına doğrudur. Eynez fayının doğrultusuna dik alınmış bir kesitte, marn tabakalarının yanısıra I ve II-nolu çatlak takımlarının konumları da gösterilmiştir (Şekil 10). I ve II nolu çatlak takımları basamaklarda "prizmatik bloklu bir yapını" gelişmesine neden olmuştur (Şekil 10). İki çatlak takımı bloğun birbirine dik yan yüzeylerini oluştururken, bloğun tabanını yamaç dışına eğimli marn tabaka düzlemleri oluşturmaktadır. Şevi kesmelerine rağmen tabakalar düzlemsel kayma potansiyeli oluşturmazlar $\left(\bar{P}_{\mathrm{SSEV}}-\bar{P}_{\mathrm{TAB}}=42^{\circ}\right.$, $\left.\alpha_{\text {şev }}>\alpha_{t a b}<\phi\right)$, (Şekil 8a ve 8b). Blok devrilmesi, şev dışına eğimli tabakalar üzerinde gerçekleşmektedir. 
Terli, Kalhan, Koca

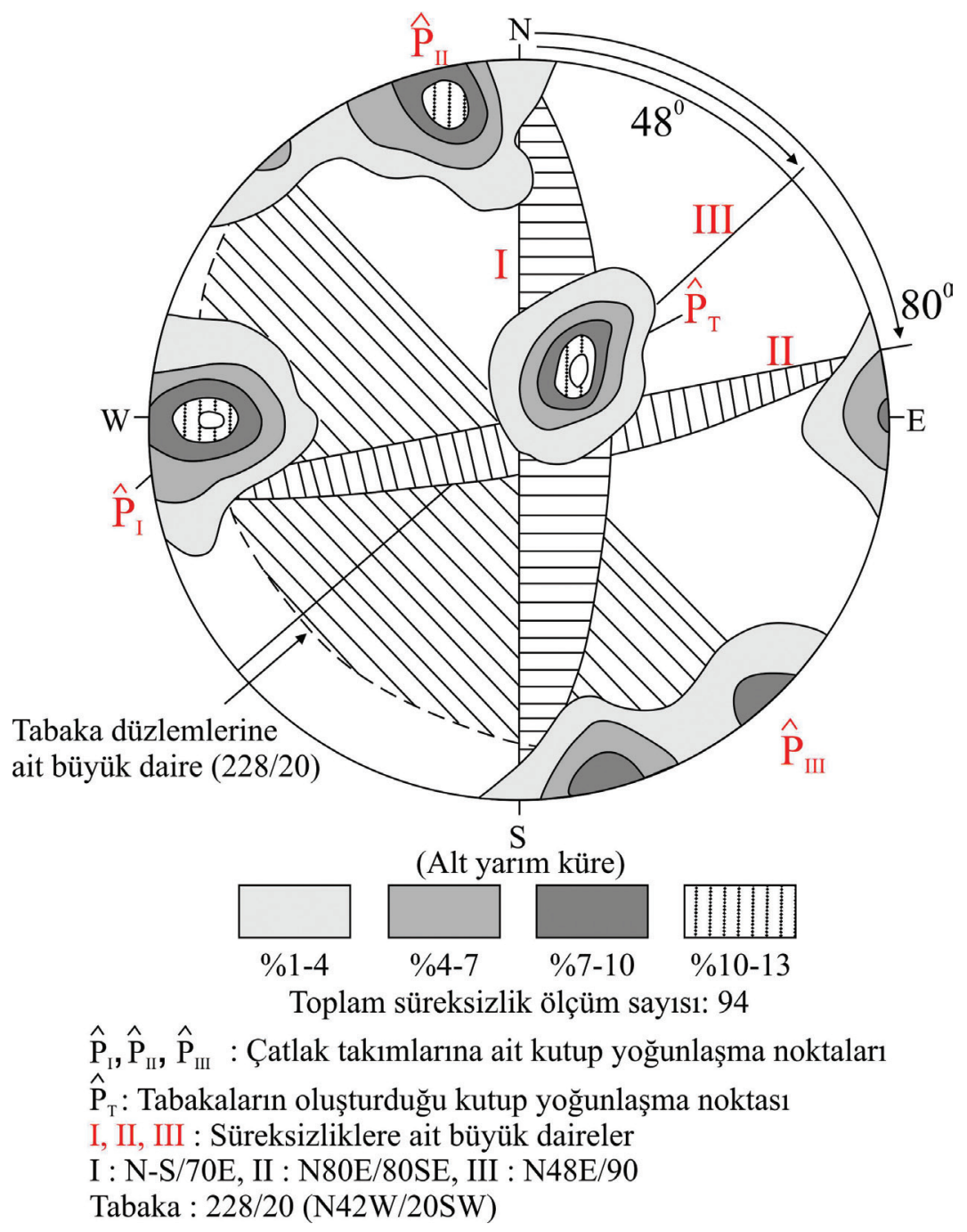

Şekil 7. 670 topuğundan alınan süreksizlik ölçülerine ait kontur diyagramı ve süreksizlik setlerine ait büyük daireler. Figure 7. Contour diagram of the discontinuity measurements taken from 670 pillar and great circles of the discontinuity sets.

670 topuğunda, I-nolu çatlak takımına ait süreksizliklerin kutup noktaları devrilme zarfının içine düşmüştür (Şekil 8a ve 8b). I-nolu çatlak takımına ait süreksizliklerin doğrultuları ile şev düzleminin doğrultusu arasındaki açı stereonet üzerinde $10^{\circ}$ olarak belirlenmiştir. Blok oluşumu gerçekleşmiş ve/veya en az iki süreksizlik takımının geliştiği şevlerde $(\mathrm{Bu}$ durumda kayaç kütlesi bloklu bir yapı kazanır) yukarıda belirlenen koşullar da gerçekleşmiş ise, kinematik olarak devrilme potansiyelinin şevde var olduğu anlaşılır. Eynez fayının düşen bloğunu oluşturan 670 topuğunda, söz konusu parametrelerin tümü mevcut olup, açık işletmede kömür üretimine yönelik örtü kazılarıyla birlikte 23 Mart 2016'dan itibaren kaya devrilmeleri şekinde gelişen kültle hareketleri de gözlenmeye başlamıştır. 


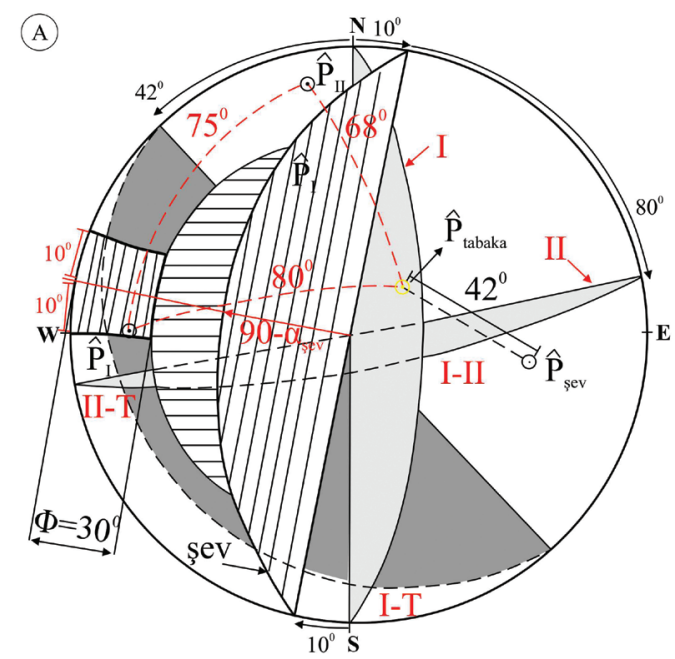

(B)

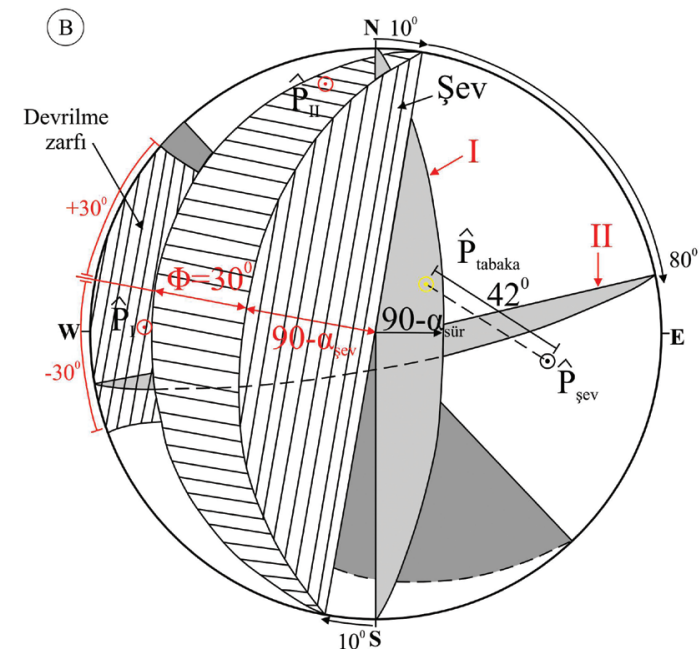

\begin{tabular}{|c|c|}
\hline A-Açıklama & B-Açıklama \\
\hline$\overline{\text { Sev: } 280 / 52}(\mathrm{~K} 10 \mathrm{D} / 52 \mathrm{~KB})$ & Sev: $280 / 52$, set-I: $90 / 70$, set-II: $170 / 80$ \\
\hline Catlak seti-I: K-G/70D, & Marn tabakalar1: $228 / 20^{\circ}(\mathrm{K} 42 \mathrm{~B} / 20 \mathrm{~GB})$ \\
\hline Çatlak seti-II: K80D/80GD, & Süreksizliklere ait sürtünme açısı, $\Phi_{r}: 30$ \\
\hline T: Tabaka, Marn tabakaları: K42B/20GB, & P: Kutup noktas1, \\
\hline nme açist $\Psi_{\mathrm{r}}=50$ & Hüzleminin e \\
\hline (Bu 1 & $\begin{array}{l}\alpha_{\text {sir }}^{*} \text { suresizingin } \\
90-\alpha_{\text {sir }}: 90-70=20^{\circ} \text {, }\end{array}$ \\
\hline arakesitler elde $\mathrm{e}$ & $\left(\alpha_{\text {sev }}-\Phi\right)=52-30=22^{\circ}$ \\
\hline$\bigcup_{n}$ :Büyük daire & Norrish \& Wyllie (1996)'a göre \\
\hline $75^{\circ} /{ }_{80^{\circ}}^{-6^{\circ}}:$ Blok oluşumu, $\hat{\mathrm{P}}_{\mathrm{sev}} \hat{\mathrm{P}}_{\mathrm{tab}}=42^{0}>\mp 20^{\circ}$ & $\begin{array}{l}\text { devrilme kosulu; } \\
\text { i. }(90-a)<\left(\alpha-(\Phi) \rightarrow 20^{\circ}<22^{\circ}\right.\end{array}$ \\
\hline $20^{\circ} \|$ :Devrilme zarfi & $\begin{array}{l}\text { ii: }+30^{\circ} \text { (Devrilme zarfinın sınırları) } \\
\text { süreksizliğin ve şevin doğrultusu } \\
\text { arasındaki aç farkı }=10^{\circ}\end{array}$ \\
\hline
\end{tabular}

Şekil 8 a) 670-topuğuna ait şevde kaya devrilmesi ve blok oluşumunu yansıtan stereogram (Hoek ve Brown, 1974'e göre) b) 670- topuğuna ait şevde kaya devrilme yenilmesi potansiyelinin varlığına işaret eden stereogram (Norrish ve Wyllie, 1996'a göre).

Figure 8. a) Stereogram reflecting the toppling failure and block-formation (according to the method suggested by Hoek and Brown 1974), b) Stereogram indicating the existing of potential toppling failure on the slope of 670 pillar (according to the method suggested by Norrish and Wyllie, 1996). 

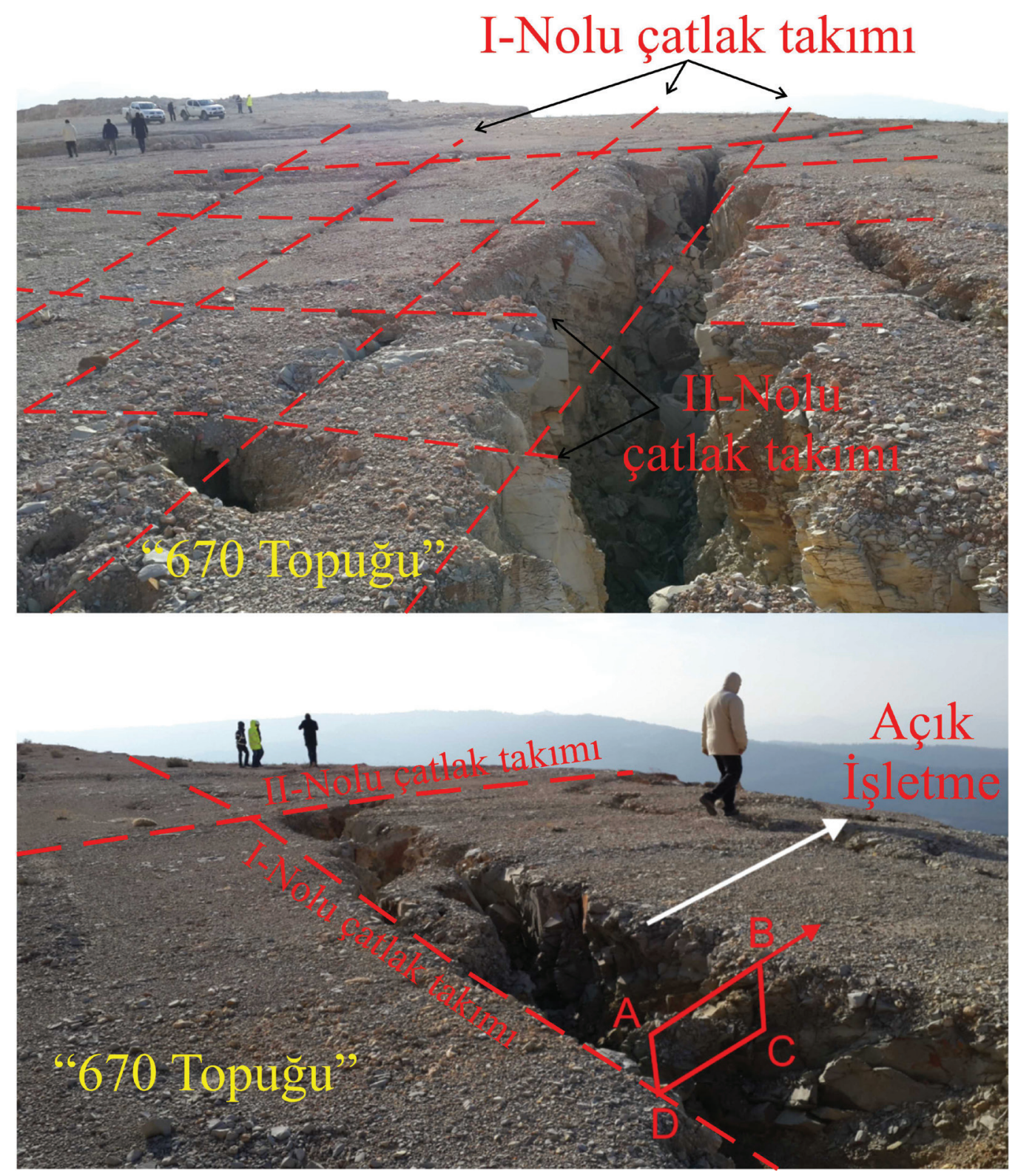

Şekil 9. a) Marnlarda çatlak takımlarının 670 topuğunun yüzeyinde oluşturduğu "bloklu yapı”, b) 670-topuğunun batı ucundaki şevde gözlenen, devrilme öncesinde gelişen blok kalkması ( $\overline{\mathrm{AB}}: 70 \mathrm{~cm}, \overline{\mathrm{BC}}: 25 \mathrm{~cm})$.

Figure 9. a) Blocky-structure formed by the joint sets in the marls on the surface of 670 pillar, b) Block uplift before the toppling failure, observed on the slope at the west end of 670 pillar $(\overline{A B}: 70 \mathrm{~cm}, \overline{B C}: 25 \mathrm{~cm})$.

\section{Blok devrilme duraysızlığı oluşan} 670-topuğuna ait şevlerde I $\alpha_{\text {şev }}-\alpha_{\text {sür }} \mathrm{I} \leq 10^{\circ}$ durumu vardır. Norrish ve Wyllie (1996)'a göre devrilme koşulu; i) $\left(90-\alpha_{\text {sür }}\right) \leq\left(\alpha_{\text {șev }}-\phi\right)$, ii)
Süreksizliğin ve şevin doğrultuları arasındaki açı farkı en fazla $30^{\circ}$ olmalıdır $\left( \pm 30^{\circ}\right)$. Bu koşulları dikkate alan stereogram Şekil 8b'de sunulmuştur. $\mathrm{Bu}$ kinematik analiz yöntemine göre de şevde 
devrilme potansiyeli vardır. Devrilme öncesinde kaya bloğu, I-nolu çatlak takımına ait süreksizlik boyunca açılmakta ve çatlaktan itibaren şev dışına doğru (öne doğru) hafifçe yükselerek Şekil 9b'de gösterilen ok yönünde açık işletmeye doğru (batıya doğru) hareket etmektedir. kaymadan, hafifçe öne doğru kalkmakta (uplift) ve daha sonra devrilmektedir (Şekil 9b). Şevde mevcut çatlaklarda bir bükülme oluşmadan doğrudan blok devrilmektedir. Şev ucunda, $\bar{P}_{\mathrm{I}}$ kutup noktasını oluşturan, dik ve dike yakın eğim değerindeki çatlaklar (Set - I), şevde

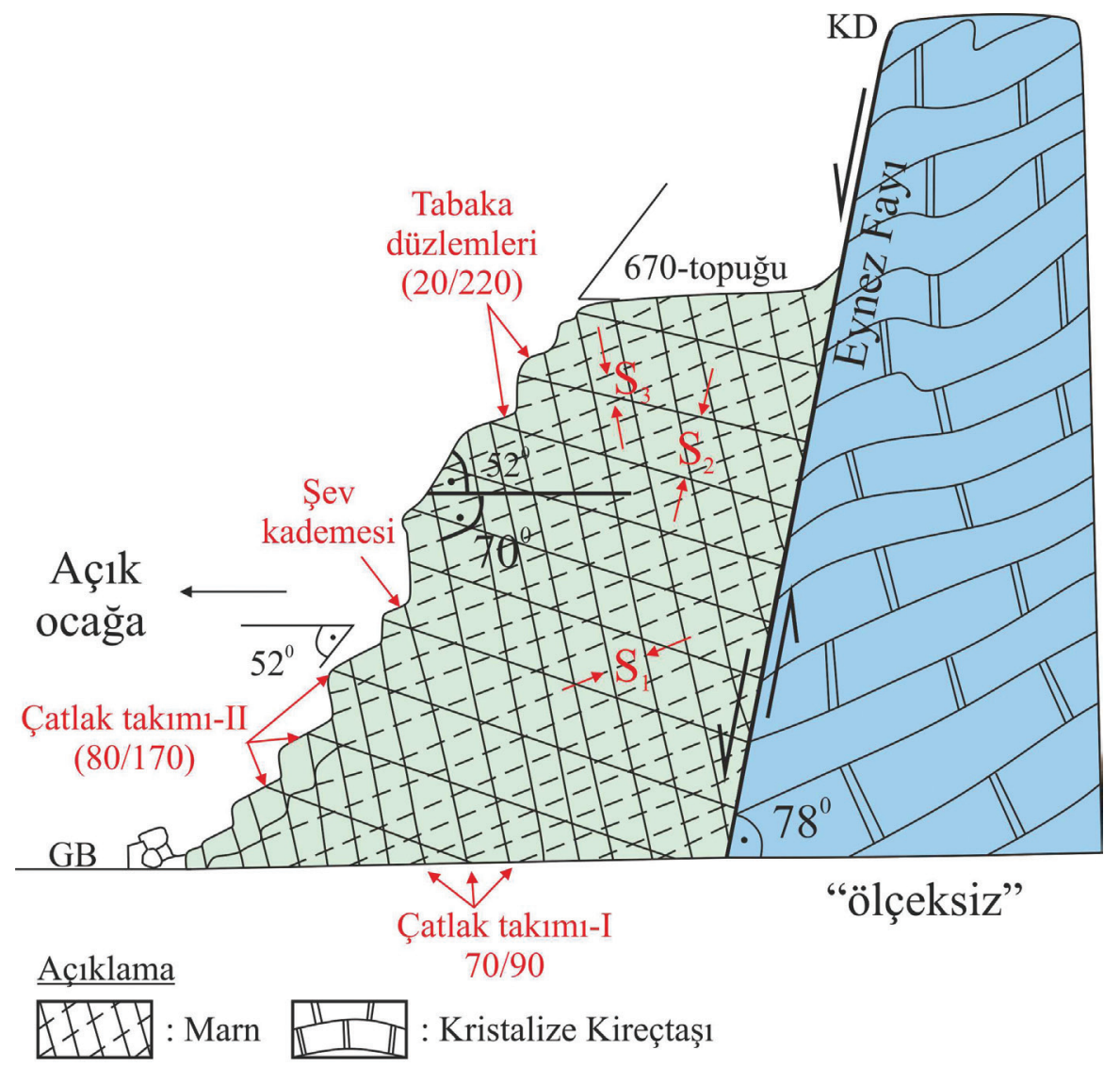

$\mathrm{S}_{2}$ : Çok geniș aralıklı, $\mathrm{S}_{1}$ : Geniş aralıklı $(0,2-0,6 \mathrm{~m})$

$\mathrm{S}_{3}$ : İnce tabakalı $(6,0-20 \mathrm{~cm})$

$\mathrm{S}_{2}$ : Çok geniş aralıklı $(0.72-2.0 \mathrm{~m}), \mathrm{S}_{1}$ : Çokgeniş aralıklı $(0.53-1.34 \mathrm{~m}), \mathrm{S}_{3}$ : Tabaka kalınlığı, ince katmanlı $(6.0-20 \mathrm{~cm})$.

Şekil 10. Eynez fayının doğrultusuna dik konumda yapılandırılmış jeolojik kesit.

Figure 10. Geological cross-section constructed in vertical position to the strike of the Eynez fault.

Devrilme yenilmesi sirasında, blokların tabanında ve kenarlarında sürtünme kuvvetleri oluşur (Wyllie ve Mah, 2004). Devrilmesi muhtemel kaya bloğu, tabaka düzlemi üzerinde devrilme hareketini destekleyen çekme (açılma) çatlakları olarak da çalışmaktadır (Şekil 9 ve 10). Yüzeye yaklaştıkça jeolojik yük azalması nedeniyle gelişen gevşeme, çatlak açıklıklarını 
artırmaktadır. Bu nedenle, dişa doğru (açık ocağa doğru) çekme gerilmeleri de derinlere göre daha yüksek değerler almaktadır. Çekme nedeniyle bu çatlaklar boyunca açılmalar meydana gelmekte ve zamanla çatlak açıklıkları büyümektedir (d $>50 \mathrm{~cm}$ ). Devrilmenin oluşabilmesi için blok tabanında ve kenarlarında (yüz-yüze temas noktalarında) makaslama yer değiştirmeleri meydana gelmektedir. Buna ek olarak, kaya bloklarının ve bunlara etki eden kuvvetlerin birlikte incelenmesiyle, süreksizlikler arasında kayma yer değiştirmelerinin oluşabilmesi için Duncan ve Mah (2004) tarafindan önerilen eşitliklerin sağlanması gerekmektedir. $\left(\alpha_{\text {sür }}>(90\right.$ $\left.-\alpha_{\text {sev }}\right)+\phi$ veya $\left(\alpha_{\text {sür }}-\phi\right)>\left(90-\alpha_{\text {sev }}\right.$ olmalidır $)$.

Norrish ve Wyllie (1996)'a göre devrilme koşulu ise; $\left(90-\alpha_{\text {sürek }}\right) \leq\left(\alpha_{\text {sev }}-\phi\right)$ olmalıdır. Goodman ve Bray (1976)'a göre; devrilme yenilmesinin oluşabilmesi için aşağıda verilen eşitliklerin (Eşitlik 1 ve 2'nin) sağlanması gereklidir.

$$
\begin{aligned}
& (\mathrm{h} / \mathrm{a})>\cot \left(90-\alpha_{\text {sür }}\right) \\
& \alpha_{\text {șev }} \geq \phi+\left(90-\alpha_{\text {sürek }}\right)
\end{aligned}
$$

Eşitlik 1 blokta rotasyonu, Eşitlik 2 ise, süreksizlikler arası kayma potansiyelini belirler. 670 topuğunda her iki eşitlik de sağlanmaktadır. Burada, $\phi$; devrilmeye neden olan süreksizlik düzlemleri arasındaki rezidüel sürtünme açısıdır ve makaslama deneylerinden elde edilmiştir $\left(\phi_{\mathrm{r}}=\right.$ $\left.30^{\circ}\right) \mathrm{h} / \mathrm{a}$ ise blok boyutlarıdır. Devrilmeye neden olan birinci takım süreksizliklere ait eğim açısı

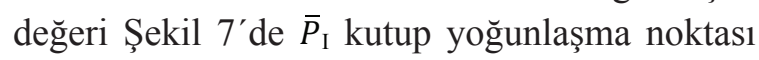
dikkate alınarak $70^{\circ}$ olarak belirlenmiştir. Şev düzleminin eğim açısı $52^{\circ}$ (overall slope angle) olarak ölçülmüştür. Veriler 1şığında; $70^{\circ}>(90-$ 52) $+\phi ; 70^{\circ}>38^{\circ}+30^{\circ} ; 70^{\circ}>68^{\circ}$ veya $70^{\circ}$ $-30^{\circ}>\left(90^{\circ}-52^{\circ}\right), 40^{\circ}>38^{\circ}$ olmasi nedeniyle 670 topuğunda blok devrilme duraysızlığ 1 meydana gelmiştir. Blok devrilmesi türünde duraysızlığın bir şevde yeralan kaya bloğunda meydana gelebilme potansiyeli, blok boyutları dikkate alınarak da incelenmelidir. Blok boyutlarını belirleyen parametre süreksizlik aralığı değerleridir. $\mathrm{Bu}$ nedenle, çalışmanın başlangıcında I ve II. takım çatlaklara ait süreksizlik aralığı değerleri araştırılmış ve ölçümlerin sonuçları grafik olarak Şekil 11'de sunulmuştur. Elde edilen grafiklerde çatlak takımları-I ve II'ye ait ortalama süreksizlik aralığı değerleri sirasıyla $0.985 \pm 0.246 \mathrm{~m}$ ve $1.21 \pm 0.342 \mathrm{~m}$ olarak belirlenmiştir (Şekil 11). Anon (1977) 'e göre, takım-I ve II'ye ait süreksizlikler "çok geniş aralıklı" olarak sınıflandırılmıştır. Marn tabakaları üzerinde bir kaya bloğunun kaymadan devrilebilmesi için, marn tabakalarının eğimlerinin $<\phi$ ve de $\left(\frac{a}{h}\right)$ blok boyutu oranının $<\tan \alpha_{\text {marn }}$ olmas1 gerekir. Marn tabakalarının kalınlıkları 7 ile $20 \mathrm{~cm}$ arasında değişmektedir ( $\overline{\mathrm{x}}=14.2 \pm 4.13 \mathrm{~cm})$. $\alpha_{\text {marn }}=20^{\circ}, \Phi_{\text {tabaka }}=24^{\circ}$, blok yüksekliklerini I'ci takım çatlaklara ait süreksizlik aralığ 1 değeri, blok genişliğini ise tabaka kalınlıkları oluşturmaktadır. Böylece, $\alpha_{\text {marn }}<\phi ; 20^{\circ} \leq 24^{\circ}$ ve $\frac{s_{3}}{s_{1}}=\left(\frac{a}{h}\right)<\tan \left(\alpha_{\text {marn }}\right) ; \frac{0.142}{0.985} ;<\tan 24 ; 0.144<$ 0.445 durumu elde edilmektedir. $20^{\circ}$ lik eğimli düzlemler üzerinde, $\mathrm{S}_{1}=0.985 \mathrm{~m}, \mathrm{~S}_{3}=0.142 \mathrm{~m}$ olması durumunda, blok ağırlı merkezinden geçen blok ağırlık vektörü, blok taban alanının dışına çıkmaktadır. Diğer taraftan, Richards ve Atherson vd. (1978)'a göre; şev dişına eğimli bir süreksizlik yüzeyi üzerinde bir kaya bloğunda $\frac{s_{3}}{s_{1}}<1.0$ durumu var ise, kaya bloklarinda potansiyel olarak devrilme duraysızlığı da vardır. 

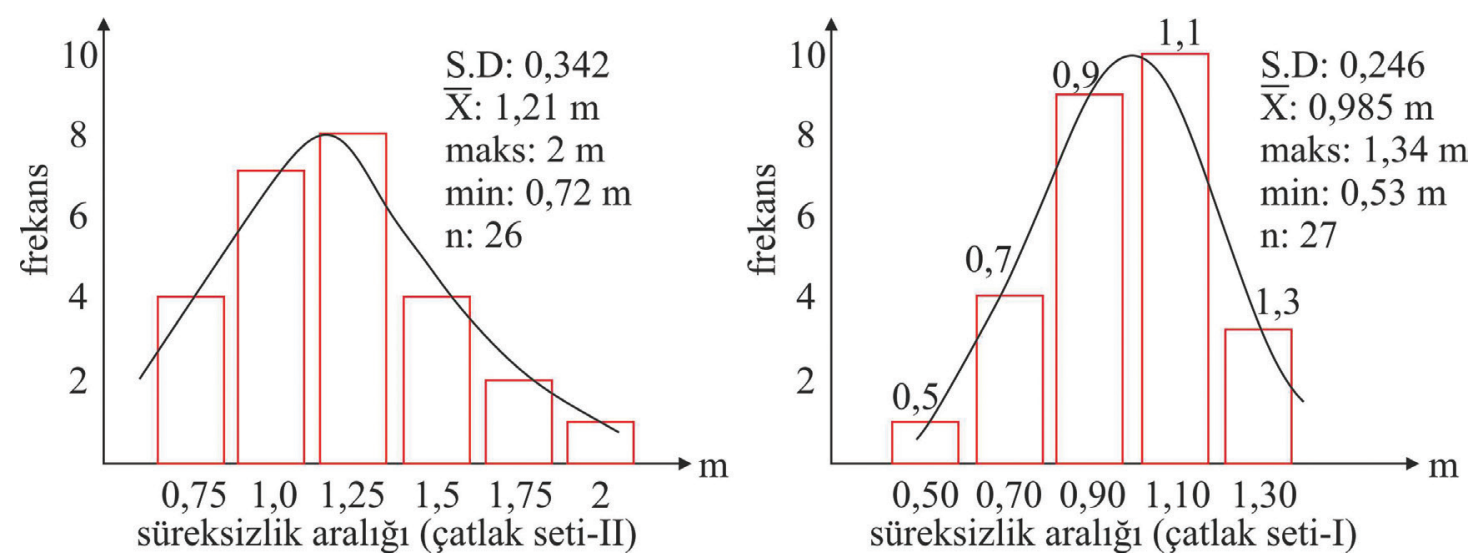

Şekil 11. 670 topuğunda, çatlak seti I ve II için süreksizlik aralığı frekans dağılımı.

Figure 11. Spacing frequency distribution for the joint set I and II in 670 pillar.

\section{Farklı Şev Yükseklikleri için Devrilme ve Duyarlılık Analizleri}

RocTopple ve Phase ${ }^{2}$ bilgisayar yazılımları kullanılarak devrilme analizleri yapılmıştır. $\mathrm{Bu}$ analizlerden elde edilen sonuçlar grafikler halinde Şekil 12 ve 13'te sunulmuştur. RocTopple yazılımı kullanılarak gerçekleştirilen analizlerde $\mathrm{H}_{\text {sev }}=74 \mathrm{~m}, \mathrm{c}=0$ için $\phi=30^{\circ}$ ve $\phi=38^{\circ}$ 'de elde edilen faktörü değerleri (FoS) arasındaki fark $0.207^{\prime}$ dir. $\mathrm{H}_{\text {sev }}=110 \mathrm{~m}$ için bu fark 0.206' dir (Şekil 12). $\mathrm{H}_{\text {sev }}=74 \mathrm{~m}, \mathrm{c}=60 \mathrm{kPa}$ için $\phi=30^{\circ} \mathrm{ve}$ $\phi=38^{\circ}$ 'de elde edilen FoS değerleri arasındaki fark $0.177^{\prime}$ dir. Şev yüksekliği 110 m'e çıktığında, aynı kohezyon değerinde ( $=60 \mathrm{kPa}), \phi=30^{\circ}$ ve $\phi=38^{\circ}$ için elde edilen FoS değerleri arasındaki fark $0.195^{\prime}$ dir (Şekil 12). Analizlerin sonucu olarak, tüm FoS değerleri için maksimum ve minimum değerler 0.207 ile 0.177 arasında yer almaktadır (1'ci grup analizler). Hem kohezyon hem de sürtünme açısı değişimlerinin birlikte dikkate alınması durumunda (2'ci grup analizler), aynı şev yükseklikleri için güvenlik faktörü değişimi aşağıdaki gibi elde edilir; $\mathrm{H}_{\text {şev }}=74 \mathrm{~m}$ için 0.446 (1.033-0.587), $\mathrm{H}_{\text {sev }}=84 \mathrm{~m}$ için 0.406 $(0.992-0.586), \mathrm{H}_{\text {sev }}=94 \mathrm{~m}$ için $0.377(0.962-$ $0.585)$ ve $\mathrm{H}_{\text {şev }}=110 \mathrm{~m}$ için $0.344(0.927-0.583)$ olarak elde edilir (Şekil 12). Sadece $\mathrm{H}_{\text {şev }}$ sabit tutulup, $\phi$ ve c değerlerinin birlikte değişken olmasi durumunda (2'ci grup analizler), FoS'da meydana gelen değişim $0.344(0.927-0.583)$ ile 0,446 (1.033-0.587) arasında bulgulanmıştır.

Phase $^{2}$ yazılımı kullanılarak gerçekleştirilen devrilme analizlerinde, $\mathrm{H}_{\text {şev }}=74 \mathrm{~m}, \mathrm{c}=0$ olması durumunda, devrilmeye neden olan çatlakların sürtünme açılarının $\phi_{\mathrm{r}}=30^{\circ}$ ve $\phi_{\mathrm{p}}=38^{\circ}$ olmas1 durumunda (1'ci grup analizler), SRF değerleri sırasıyla 0.71 ve 0.80 olarak elde edilmiştir (Şekil 13). SRF değerleri arasındaki fark $0.09^{\prime}$ dur. $\mathrm{H}_{\text {şev }}=110 \mathrm{~m}$ olması durumunda, aynı koşullarda elde edilen SRF değerleri sirasiyla 0.65 ve 0.73 'dür. iki SRF değeri arasındaki fark $0.08^{\prime}$ dir. $\mathrm{H}_{\text {şev }}=74 \mathrm{~m}, \mathrm{c}=60 \mathrm{kPa}$ olması durumunda, $\phi_{\mathrm{r}}=30^{\circ}$ ve $\phi_{\mathrm{p}}=38^{\circ}$ için elde edilen SRF değerleri sırasıyla 0.87 ve $0.95^{\prime}$ dir. İki SRF değeri arasındaki fark $0.08^{\prime}$ dir. Özetle aynı kohezyon değerlerinde ve aynı şev yükseklikleri için $\phi_{\mathrm{r}}=30^{\circ}$ ve $\phi_{\mathrm{p}}=38^{\circ}$ olması durumlarında (1'ci grup analizler) SRF değerlerindeki değişim 0.09 ve 0.08 arasında elde edilmiştir. Çatlakların hem kohezyon hem de sürtünme açısı değişimlerinin etkisinin birlikte dikkate alınması durumunda (2. grup analizler), aynı şev yükseklikleri için SRF değişimi 
aşağıdaki gibi elde edilir; $\mathrm{H}_{\text {şev }}=74 \mathrm{~m}$ için 0.240 $(0.95-0.71)$ ve $\mathrm{H}_{\text {sev }}=110 \mathrm{~m}$ için 0.190 'dır $(0.84-$ 0.65) (Şekil 13). c ve $\phi$ 'nin birlikte çalışması durumunda, SRF değerlerindeki değişimler 0.19 ile 0.24 arasındadır. c ve $\phi$ 'nin birlikte değişken olması durumunda, FoS'daki değişimlerden, RocTopple yazılımı Phase ${ }^{2}$ yazılımına göre $\% 50$ oranında daha çok etkilenmiştir. $\mathrm{H}_{\text {sev }}$ ve $\phi$ sabit, kohezyonun (c) güvenlik faktörü üzerine etkisi farklı bilgisayar yazılımlarıyla incelenmiştir (Şekil 14a ve 14b). Grafiklerden kohezyon arttıkça güvenlik faktörü değerlerinin her ikisinin de (SRF ve FoS) arttığı görülmektedir. Şekil $14 \mathrm{a}$ ve $14 \mathrm{~b}^{\prime}$ de verilen grafiklerin görünümleri birbirinden oldukça farklıdır. Düşük kohezyon değerlerinde, RocTopple yazılımında, şev yüksekliğinden sonuçlar fazla etkilenmezken, Phase $^{2}$ yazılımında kohezyon doğrudan etkilenmiştir.

Şekil 14a'da farklı şev yüksekliklerinde, sifir kohezyon değerinden $60 \mathrm{kPa}$ değerine doğru "c-FoS" doğrularının bir noktadan çıkan 1şınsal bir demet şeklinde ve giderekten birbirinden uzaklaşarak yayılmış oldukları gözlenir. Şekil 14b'de bu doğrular göreceli daha düşük eğimde ve yaklaşık birbirleriyle paralel bir uzanım sunarlar (Şekil 14b). Buna ek olarak, Şekil $14 \mathrm{a}^{\prime}$ da $\phi=38^{\circ}$ ve $\phi=30^{\circ}$ için elde edilen "c-FoS" doğruları iki ayrı grup halinde gözlenirken, Şekil 14b'de "c-SRF" doğruları birbirleriyle iç içe bir görünüm sunar. $\mathrm{Bu}$ farklı görünümün nedeni; Şekil $14 \mathrm{a}$ 'da "cFoS" doğrularının oluşturduğu 1şın demetlerinin kohezyon ve sürtünme açısı artışından, Şekil $14 b^{\prime}$ dekilere göre göreceli daha çok etkilenmiş olmasındandır. $\phi$-değeri $30^{\circ}$ den $38^{\circ}$ e çıkarken, c $=60 \mathrm{kPa}$ olması durumunda, SRF değerlerindeki değişim 0.19'dur. Aynı durumda, RocTopple yazılımından elde edilen FoS değerlerindeki değişim ise 0.301 mertebesindedir. $\mathrm{Bu}$ durum aşağıda verildiği gibi de örneklenebilir. $\mathrm{c}=$ $0 \mathrm{kPa}$ olması durumunda, SRF'deki değişim 0.15 seviyesindeyken, aynı durumda, FoS değerindeki değişim $0.217^{\prime}$ dir. $\phi$-açısının yanısıra kohezyon değeri artışı da güvenlik faktörü değerlerinin arasını açmaktadır (FoS ve SRF değerlerinin arası açılmaktadır). RocTopple programında, $\phi$ açısının $30^{\circ}$ ve $38^{\circ}$ olması durumlarında, kohezyon değeri sıfıra yaklaştıkça,

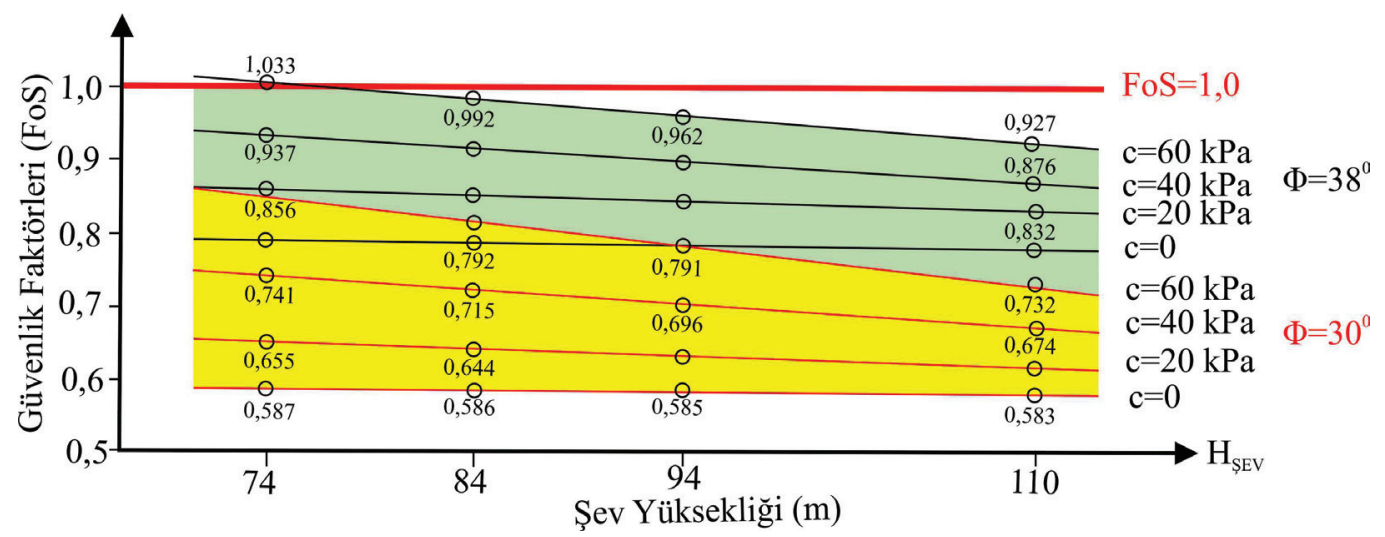

Şekil 12. Farklı kohezyon ve sürtünme açısı değerleri için şev yüksekliği değişiminin güvenlik faktörü üzerindeki etkisi (analizler RocTopple bilgisayar yazılımı kullanılarak gerçekleştirilmiştir).

Figure 12. The effect of the slope height variation on the factor of safety (FoS) for various cohesion and friction angle values (analyses were performed by using the RocTopple software). 


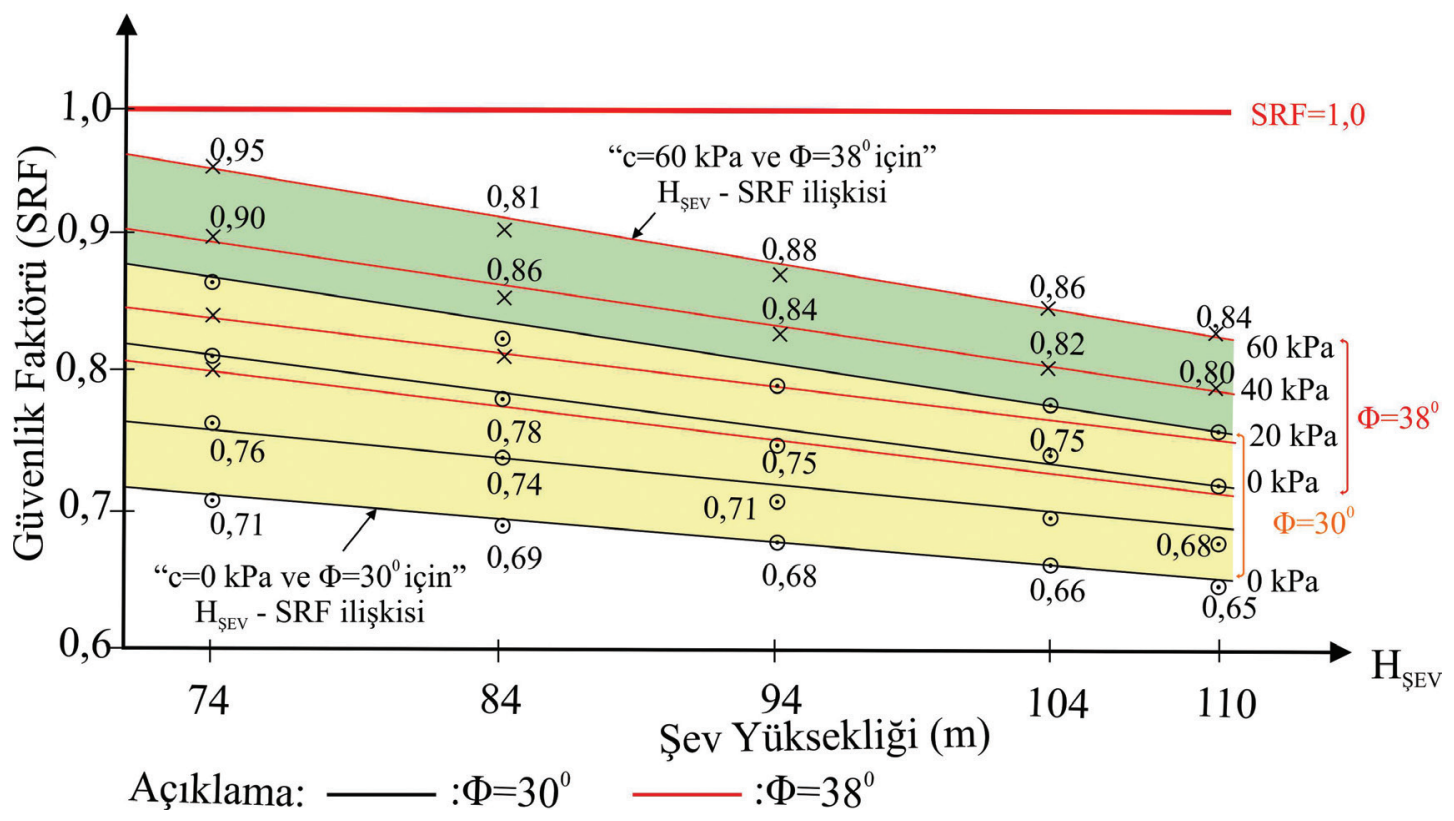

Şekil 13. Farklı kohezyon ve sürtünme açısı değerleri için şev yüksekliği değişiminin güvenlik faktörü üzerindeki etkisi (analizler Phase ${ }^{2}$ bilgisayar yazılımı kullanılarak gerçekleştirilmiştir).

Figure 13. The effect of the changes of slope height on factor of safety for various $c$ and $\phi$ values (analyses were performed by using Phase ${ }^{2}$ software).

FoS değerleri birbirine çok yaklaşmaktadır (Şekil 14a). Farklı yazılımlarla aynı şevin devrilme yenilmeleri açısından stabilite incelemesinde ikinci bir konu daha bu araştırmada dikkat çekmiştir. $\phi=30^{\circ}$ 'de, SRF değerleri, RocTopple yazılımından elde edilen FoS değerlerinden daha büyüktür ( $\mathrm{SRF}>\mathrm{FoS}$ ), (Güvenlik faktörleri arasındaki fark 0.014 ile 0.123 arasında değişmektedir). Buna karşın, $\phi=38^{\circ}$ de, FoS > SRF durumu oluşmaktadır (Güvenlik faktörleri arasındaki fark 0.012 ile 0.083 arasında değişmektedir). Bunun nedeni; $\phi$-açısı artışına RocTopple yazılımının göreceli çok daha hassas olmasıdır. Derin şevler için gerek SRF $>$ FoS gerekse de FoS $>$ SRF durumlarında, heriki güvenlik faktörü arasındaki fark stabiliteyi doğrudan etkileyecek düzeyde bir büyüklüğe sahip değildir $(\leq 0.123)$. Bu nedenle, her iki yazılımdan elde edilen güvenlik faktörleri karşılaştırmalı olarak dikkate alındığında, açık ocak derin şevlerinin devrilme duraysızlığ incelemelerinde güvenli olarak kullanılabileceği sonucu ortaya çıkmaktadır.

Kaya devrilme duraysızlığı için Phase ${ }^{2}$ ve RocTopple programlarının aynı şev için uygulanmasında dikkat çeken üçüncü bir konu; $\phi=30^{\circ}$ ve $\phi=38^{\circ}$ durumlarında kohezyonun etkisinin incelenmesi olmuştur. Şekil $14 \mathrm{a}$ ve $14 b^{\prime}$ de verilen grafiklere bakıldığında; $H_{\text {șev }}$ ve $\phi$ sabit durumda, c-değeri arttıkça güvenlik faktörü de artmıştır. Diğer taraftan, $\phi=30^{\circ}$ ve SRF > FoS durumunda, kohezyon sifir değerindeyken elde edilen SRF - FoS fark1, $60 \mathrm{kPa}$ olmas1 durumunda elde edilen SRF - FoS farkından daha büyüktür. Buna ek olarak, $H_{\text {sev }}$ değeri arttıkça bu fark küçülmektedir. $\mathrm{H}_{\text {sev }}=74 \mathrm{~m}$ için SRF - FoS değeri 0.014 ile $0.123, \mathrm{H}_{\text {şev }}=84 \mathrm{~m}$ için 0.022 ile 
$0.104, \mathrm{H}_{\text {şev }}=94 \mathrm{~m}$ için 0.028 ile 0.095 ve $\mathrm{H}_{\text {şev }}$ $=110 \mathrm{~m}$ için 0.028 ile 0.067 arasındadır. Diğer taraftan, $\phi=38^{\circ}$ ve FoS $>$ SRF için, kohezyon $60 \mathrm{kPa}$ olması durumunda, elde edilen FoS SRF fark1, sıfir $\mathrm{kPa}$ olması durumunda elde edilen FoS - SRF farkından daha büyüktür.
Buna ek olarak, $\mathrm{H}_{\text {şev }}$ arttıkça bu fark, SRF - FoS durumundaki gibi küçülmektedir. Kohezyon etkisi kısaca özetlenirse, SRF - FoS fark1 (SRF $>$ FoS durumunda) kohezyon sifirken FoS - SRF fark1 ise (FoS $>$ SRF durumunda) kohezyon 60 $\mathrm{kPa}$ değerindeyken daha büyük elde edilmiştir.

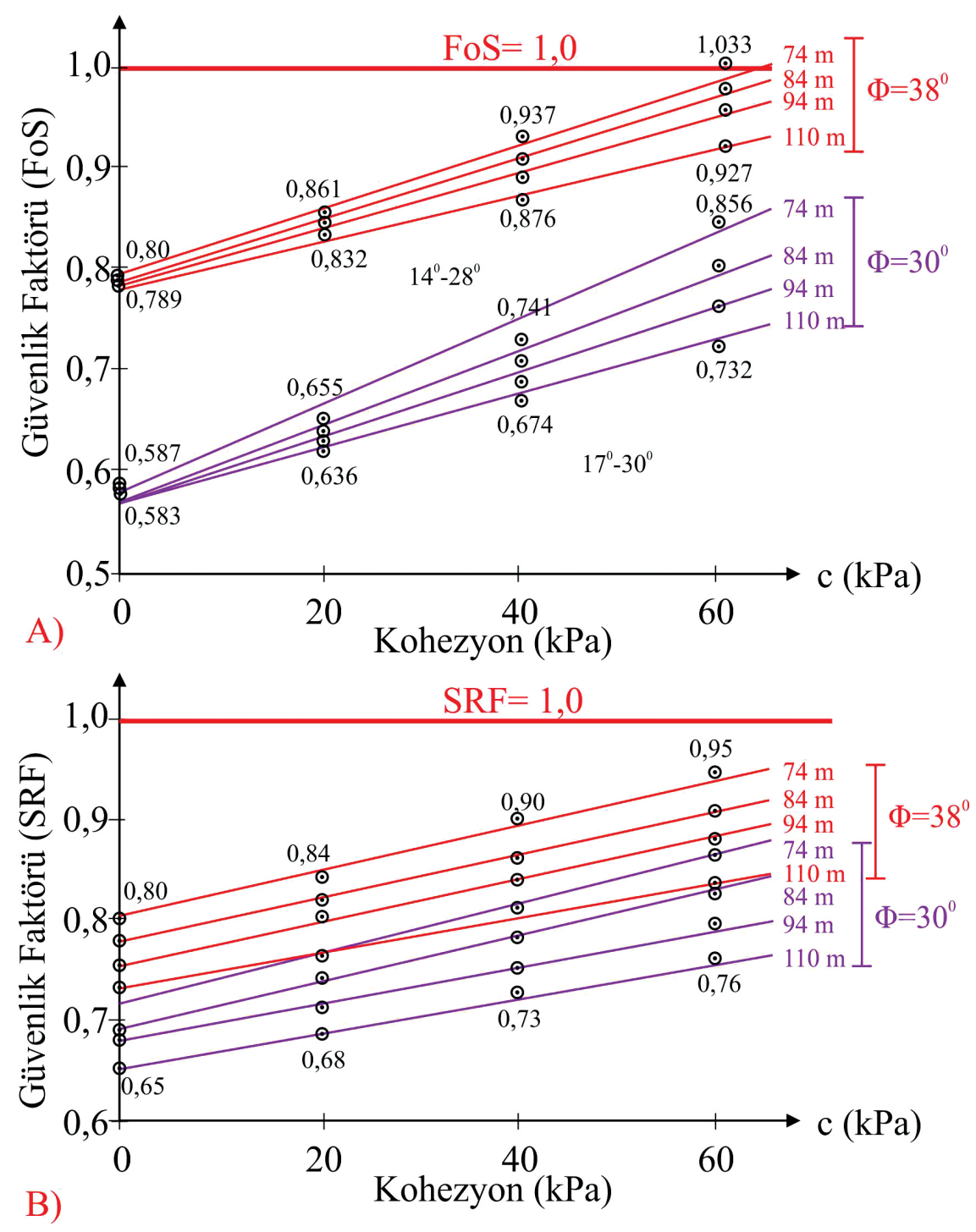

Şekil 14. Kohezyon ve sürtünme açısının güvenlik faktörü üzerine etkisi a) RocTopple yazılımı kullanılarak yapılan inceleme b) Phase ${ }^{2}$ yazılımı kullanılarak yapılan inceleme.

Figure 14. The effect of cohesion and internal friction angle on the factor of safety a) Examination using the RocTopple software b) Examination using the Phase ${ }^{2}$ software. 


\section{Düşen Kaya Parçalarının Maksimum Yuvarlanma Mesafelerinin Belirlenmesi}

670 topuğuna ait şevin 109 m yüksekliğe eriştiği arazi kesimleri, KD - GB gidişli fay hattının yeraldığı topuğun kuzey kesimleridir $\left(\mathrm{H}_{\text {sev }}: 677.7 \mathrm{~m}-569.7 \mathrm{~m}=109 \mathrm{~m}\right)$. Söz konusu şev boyunca, şev yüksekliği baskın olarak $74 \mathrm{~m}-94 \mathrm{~m}$ arasında değişmektedir. Şevin güney kesimlerinde, şev yüksekliği $73 \mathrm{~m}$ 'e kadar düşmektedir $(626.9 \mathrm{~m}-554.1 \mathrm{~m}=73$ $\mathrm{m})$. Kaya düşmesi analizleri 670 topuğundan düşen, yuvarlanan kaya bloklarının batı yönünde yatay olarak maksimum yuvarlanma mesafeleri ve maksimum sıçrama yükseklikleri farklı şev yükseklikleri (74 $\mathrm{m} \leq \mathrm{H}_{\text {șev }} \leq 110$ m) dikkate alınarak RocFall v.4.0 bilgisayar yazılımı kullanılarak incelenmiştir. Devrilen kaya bloklarının yuvarlanarak ve sıçrayarak ulaşabilecekleri maksimum yuvarlanma mesafelerinin analizi "proje kazı sınırının" belirlenmesi için yapılmıştır. Böylece, 670 topuğunun şevi ile proje kazı sınırı arasındaki düzlük alan ikinci emniyet topuğu olarak $(162 \times$ $10^{3} \mathrm{~m}^{2}$ ) belirlenmiştir. 670 topuğunun güneyinde bu mesafe $135 \mathrm{~m}$, GB'da ve topuğun tam batısında bu alan $200 \mathrm{~m}$ olarak belirlenmiş ve Şekil 1'deki haritaya (1/2000 ölçekli) işlenmiştir (yeşil renkli alan). İkinci emniyet topuğunun batısında kalan alanlarda kömür üretimi güvenli bir şekilde yapılmıştır. RocFall v.4.0 yazılımında kullanılan parametreler Çizelge 2 ' de toplu olarak verilmiştir.

Kaya düşme analizleri kapsamında, RocFall v.4.0 istatistiksel yazılımı kullanılarak 500 adet kaya düşürülmüştür. Kaya düşme yüksekliği (kaynak zon) her şev yüksekliği için kaya şevinin üst noktası olarak belirlenmiştir. Kaya şevinin üst noktasından gerçekleştirilen, kaya düşme analizlerinin sonucu Çizelge 3'te sunulmuştur. $74 \mathrm{~m}$ yüksekliğe sahip kaya şevindeki kaya düşmelerine ait program çıktısı Şekil 15'te verilmiştir. Kaya düşme analizinin gerçekleştirildiği profildeki (şev yüzeyi) kaya biriminin normal geri verme katsayıs $\left(R_{n}\right)$ 0.53 , teğetsel geri verme katsayısı $\left(R_{t}\right) 0.99$ olarak alınmıştır (Rocscience Inc., 2004). Kaya birimine ait bu normal ve teğetsel geri verme katsayıları düşen kaya bloğunun ulaşacağı maksimum yuvarlanma mesafesinin ve siçrama yüksekliğinin belirlenmesinde doğrudan etkili olmaktadır.

Çizelge 2. RocFall v.4.0 yazılımında kullanılan parametreler.

Table 2. The parameters used in RocFall v.4.0 software.

\begin{tabular}{lc}
\hline Parametre & Değer \\
\hline Kaya Düşürme Sayısı & 500 \\
\hline Normal geri verme katsayısı $\left(\mathrm{R}_{\mathrm{n}}\right)$ & $0.53 \pm 0.04$ \\
\hline Teğetsel geri verme katsayısı $\left(\mathrm{R}_{\mathrm{t}}\right)$ & $0.99 \pm 0.04$ \\
\hline Yüzey sürtünme açısı $(\phi)$ & $30^{\circ}$ \\
\hline Profil pürüzlülüğü & 0 \\
\hline İlk hız $(\mathrm{m} / \mathrm{s})$ & $1 \pm 0.5$ \\
\hline En düşük hı kesme değeri $(\mathrm{m} / \mathrm{s})$ & 0.1 \\
\hline
\end{tabular}

Şekil 15'te verilen grafikte yatay eksen (horizontal location of rock end-points) düşen kaya bloklarının kaç metrede durduğunu göstermektedir. Düşey eksen ise, toplam 500 adet kaya düşmesinden kaç tanesinin hangi metrede olduğunu gösteriyor. Örneğin, 74 m yükseklikten düşen kaya bloklarından 80'e yakını 155 metrede durmuştur. 
Terli, Kalhan, Koca

Çizelge 3. Farklı şev yükseklikleri için blok yuvarlanma mesafeleri.

Table 3. Block runout distances for various slope heights.

\begin{tabular}{cccc}
\hline $\begin{array}{c}\text { Şev } \\
\text { açıs1 } \\
\left({ }^{\circ}\right)\end{array}$ & $\begin{array}{c}\text { Şev } \\
\text { yüksekliği } \\
(\mathrm{m})\end{array}$ & $\begin{array}{c}\text { Düşen kaya } \\
\text { bloğunun } \\
\text { eriştiği } \\
\text { maksimum } \\
\text { mesafe } \\
(\mathrm{m})\end{array}$ & $\begin{array}{c}\text { Maksimum } \\
\text { blok siçrama } \\
\text { yüksekliği } \\
(\mathrm{m})\end{array}$ \\
\hline 52 & 64 & 135 & 3.50 \\
\hline 52 & 74 & 155 & 5.00 \\
\hline 52 & 84 & 185 & 8.00 \\
\hline 52 & 94 & 190 & 9.00 \\
\hline 52 & 100 & 260 & 11.5 \\
\hline 52 & 110 & 270 & 13.0 \\
\hline
\end{tabular}

ikinci emniyet topuğuna ait düzlük üzerinde yer almaktadır (Şekil 16). 30 Mart 2016 ile 02 Haziran 2016 tarihleri arasında (toplam 64 gün) ölçüm noktalarındaki hareket miktarları ve hareket yönleri okunmuş ve bu veriler Şekil 16 'daki harita üzerine işlenmiştir. Ikinci emniyet topuğu üzerinde yer alan ölçüm noktalarında kayda değer yer değiştirmeler gözlenmemiştir. Bu nedenle 1, 9, 10, 11, 18, 19, 20, 21 ve 22 nolu noktalarda ölçümler sürdürülmemiştir. Çizelge 4'te ölçüm noktalarında saptanan hareket miktarları ve yönleri verilmiştir. En yüksek hareket miktarları sirasıyla 26, 27, 30, ve 31 nolu ölçüm noktalarında meydana gelmiştir. $\mathrm{Bu}$ noktalardaki hareket miktarları $>25 \mathrm{~cm}$ mertebesindedir. Maksimum hareket

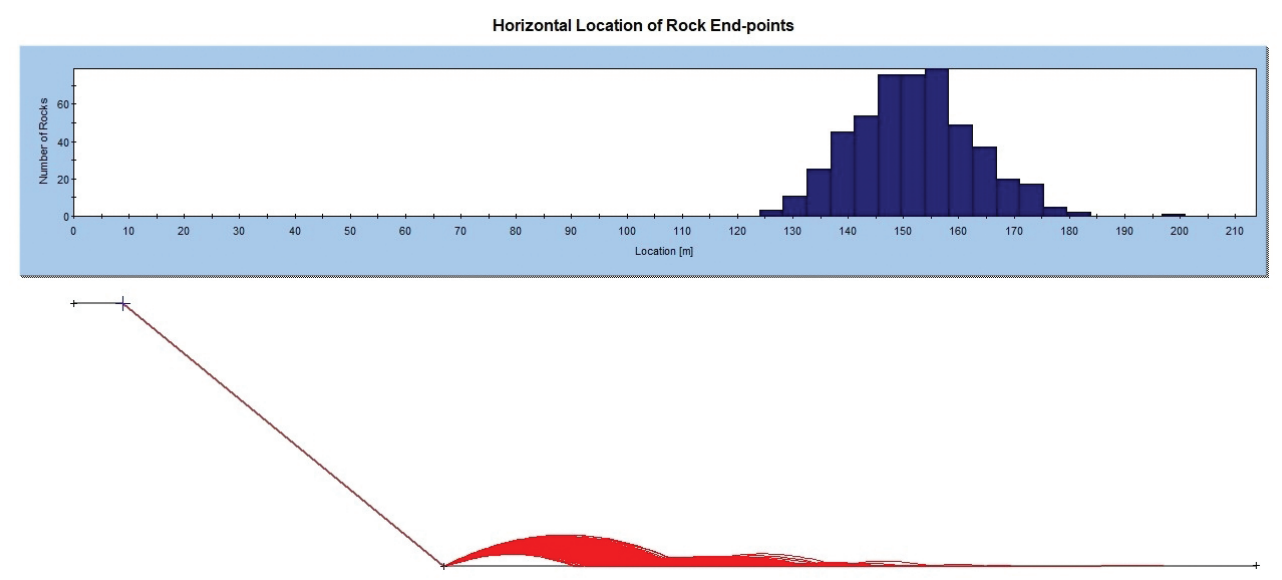

Şekil 15. 74 m yükseklikten düşen kaya bloklarının maksimum yuvarlanma mesafeleri.

Figure 15. Maximum runout distances of rock blocks falling from a height of $74 \mathrm{~m}$.

\section{Topuğu Üzerinde Yeralan Çatlaklarda Ölçülen Hareket Miktarları ve Yönleri}

670 topuğu ve ikinci emniyet topuğu üzerinde konumlandırılmış 20 adet ölçüm noktasında farklı tarihlerde çatlak açıklık ölçümleri şev izleme çalışmaları kapsamında gerçekleştirilmiştir. Ölçüm noktalarından sadece 11 adedi 670 topuğuna, 9 adedi ise miktarı 27 nolu ölçüm noktasında $60.53 \mathrm{~cm}$ olarak meydana gelmiştir. Şekil 16'daki haritada hareket miktarları konturlanmıştır. Böylece, 670 topuğu üzerinde en çok yer değiştirme hareketinin gözlendiği alanlar açıkça izlenebilir hale getirilmiştir. Burada, kontur yönelimlerinin II. takım süreksizliklerin doğrultularıyla tam olarak uyuştuğu dikkati çekmektedir. 


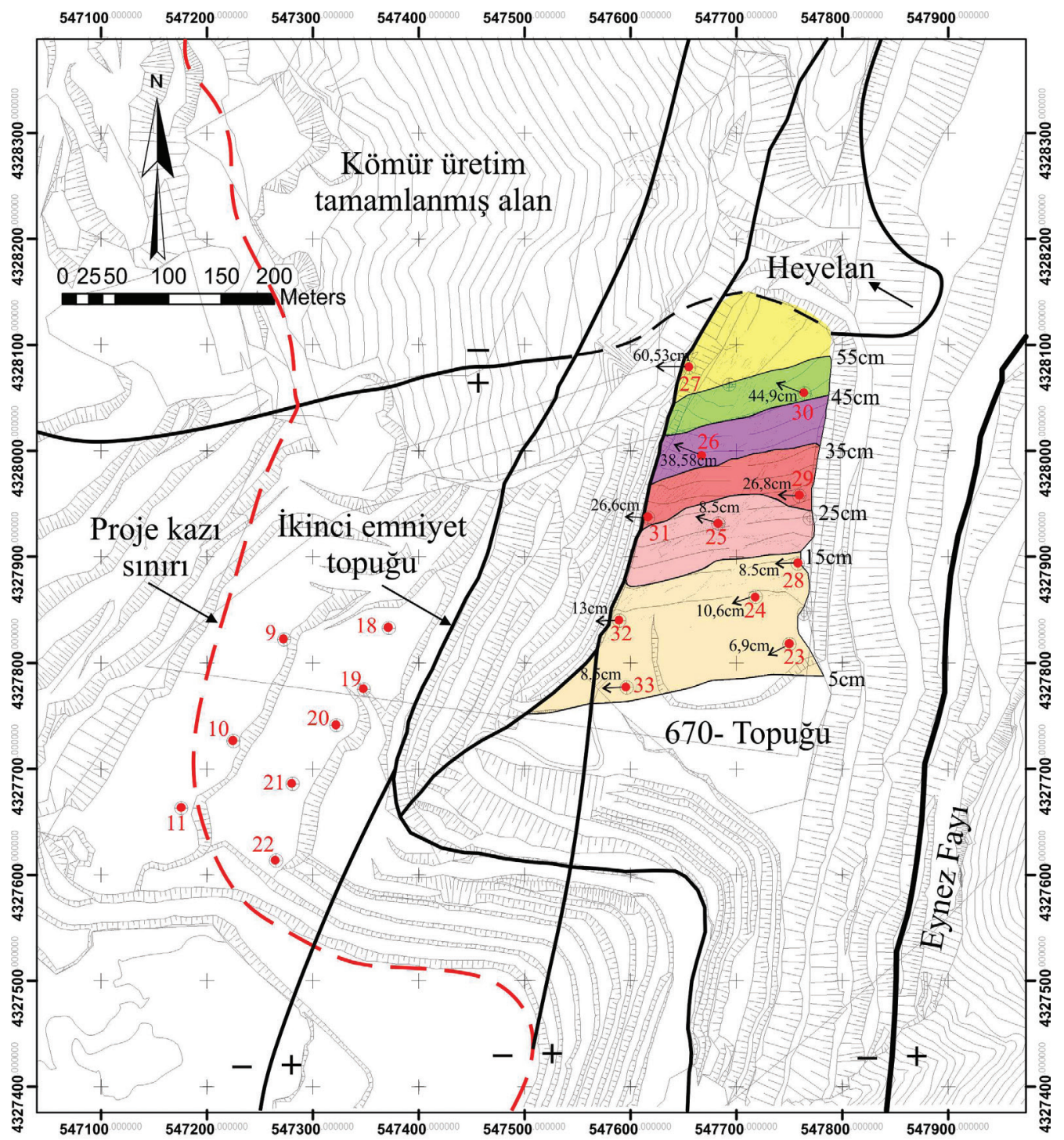

\section{$\underline{\text { AÇIKLAMA }}$}
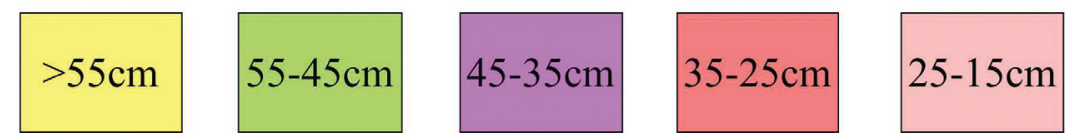

\section{$15-5 \mathrm{~cm}$}

Şekil 16. 30 Mart 2016 - 02 Haziran 2016 tarihleri arasında, ölçüm noktalarında kaydedilen hareket miktarlarının konturlanması ve kütle hareketi yönleri $(1,9,10,11,18,19,20,21$ ve 22 nolu gözlem noktalarında kayda değer yer değiştirmeler gözlenmemiştir).

Figure 16. Contouring displacement rates recorded at the measurements points in the time period between 30 March 2016 and 02 Jun 2016 and the mass movement directions (no significant displacements have been measured at the observation points of $1,9,10,11,18,19,20,21$ and 22). 
670 topuğunun en kuzeyinde, 27 nolu ölçüm noktasının yer aldığı saha (harita üzerinde sarı renge boyanmıştır) bat1-kuzeybatı yönlü devrilme türündeki şev hareketlerinin en yoğun olarak gözlendiği alandır. Bu ölçüm noktasında sadece $\mathrm{V}>1.0 \mathrm{~cm} /$ gün değeri saptanmıştır (Çizelge 4). Haritanın güneyine doğru gidildikçe hareket miktarı azalmakta ve nihayet 33-nolu ölçüm noktasında $5.50 \mathrm{~cm}$ 'e kadar inmektedir. 23 nolu ölçüm noktasında hareketin yönü G 65 B' dır. $\mathrm{Bu}$ lokasyonda gözlenen hareket 670-topuğunda gözlenen şev hareketlerinden bağımsız yersel bir hareket olarak yorumlanmıştır. 24, 31, 32 ve 33 nolu ölçüm noktalarında hareket yönü GBB, diğer ölçüm noktalarında ise KBB'dır (Çizelge 4). Çatlaklardaki açılma yönlerinin hem ana çatlak takımlarıyla hem de şev düzleminin doğrultusuyla olan ilişkileri Şekil 17'de verilmiştir.

5 adet noktanın $(23,24,31,32$ ve 33 nolu ölçüm noktalarında) hareket yönü GBB, 27 nolu ölçüm noktası hariç diğer noktalarda $(25,26,28$, 29 ve 30 nolu noktalar) hareket yönü ise KBB olarak ölçülmüştür. 27 nolu ölçüm noktasında çatlak açılması ilerleme yönü tam olarak batıdır. KBB ve GBB yönelimli ölçümlerin batıya olan yön farklarının ortalamaları alınarak iki yön elde edilmiştir. GBB'a yönelimli olanların ortalama hareket yönü G 80 B, KBB'a yönelimli olanların ise K 70 B'dır (Şekil 17). Elde edilen iki yönün, batıya olan yön farklarının ortalaması alınarak, ortalama hareket yönü K 85 B olarak elde edilmiştir. Ortalama çatlak açılım yönüyle hem çatlak takımı -I' in hem de şev düzleminin doğrultuları arasındaki açı farkı $85^{\circ}$ olarak belirlenmiştir (Şekil 17). Blok devrilme yenilmesinde, devrilen kaya bloklarının hareket yönü yaklaşık şevin eğim yönünde, çatlak takımı -I' i oluşturan süreksizliklerin doğrultularına dik, çatlak takımı -II'i oluşturan süreksizliklerin doğrultularına paralel yönde gelişmiştir (Şekil 17). Bu ilişkiler Şekil 9a ve 9b'de de açık olarak izlenebilmektedir.

Çizelge 4. Ölçüm noktalarında saptanan hareket miktarları, yönleri ve hızları.

Table 4. Displacement rates, directions and velocities at the measurement points.

\begin{tabular}{|c|c|c|c|c|c|c|c|}
\hline \multirow{2}{*}{$\begin{array}{l}\text { Ölçüm } \\
\text { noktası }\end{array}$} & \multicolumn{2}{|c|}{$\begin{array}{c}30 \text { Mart 2016-2 Haziran } 2016 \\
\text { arasındaki devre }\end{array}$} & \multicolumn{4}{|c|}{$\begin{array}{c}8 \text { Eylül } 2015 \text { - } 2 \text { Haziran } 2016 \text { arasına } \\
\text { ait devre }\end{array}$} & \multirow{2}{*}{$\begin{array}{c}30 \text { Mart } 2016 \text { - } 02 \text { Haziran } \\
2016 \text { ağırlıklı ortalama hız } \\
\text { değerleri (mm/gün) }\end{array}$} \\
\hline & $\begin{array}{c}\text { Hareket } \\
\text { miktarı }(\mathrm{cm})\end{array}$ & Hareket yönü & \multicolumn{4}{|c|}{$\begin{array}{l}\text { Ölçüm noktalarındaki hız değişimleri } \\
\mathrm{mm} / \text { gün }\end{array}$} & \\
\hline 23 & 6.90 & G65 B & 0.82 & 2.77 & 3.98 & 0.66 & 2.43 \\
\hline 24 & 10.60 & G 79 B & 1.16 & 4.24 & 1.55 & 0.84 & 1.95 \\
\hline 25 & 14.40 & K 72 B & - & - & 3.54 & 2.82 & - \\
\hline 26 & 38.53 & K $80 \mathrm{~B}$ & 6.50 & 8.26 & 5.99 & 4.65 & 6.05 \\
\hline 27 & 60.53 & K $90 \mathrm{~B}$ & 12.54 & 4.54 & 9.30 & 17.68 & 13.0 \\
\hline 28 & 15.40 & K 60 B & - & 4.53 & 2.15 & 1.13 & 2.36 \\
\hline 29 & 26.80 & K 73 B & - & 5.11 & 4.93 & 3.18 & 4.31 \\
\hline 30 & 44.90 & K 70B & 6.72 & 8.17 & 8.08 & 5.39 & 7.09 \\
\hline 31 & 26.60 & G 87 B & 5.30 & 6.77 & 3.63 & 3.47 & 4.35 \\
\hline 32 & 7.30 & G 83 B & - & 3.29 & 0.70 & 1.02 & 1.46 \\
\hline 33 & 5.50 & G $85 \mathrm{~B}$ & - & 2.93 & 0.30 & 1.06 & 1.24 \\
\hline
\end{tabular}

:> $25 \mathrm{~cm}$ olan ölçüm lokasyonları

: V>1.0 cm/gün kütle hareketi riski vardır. 


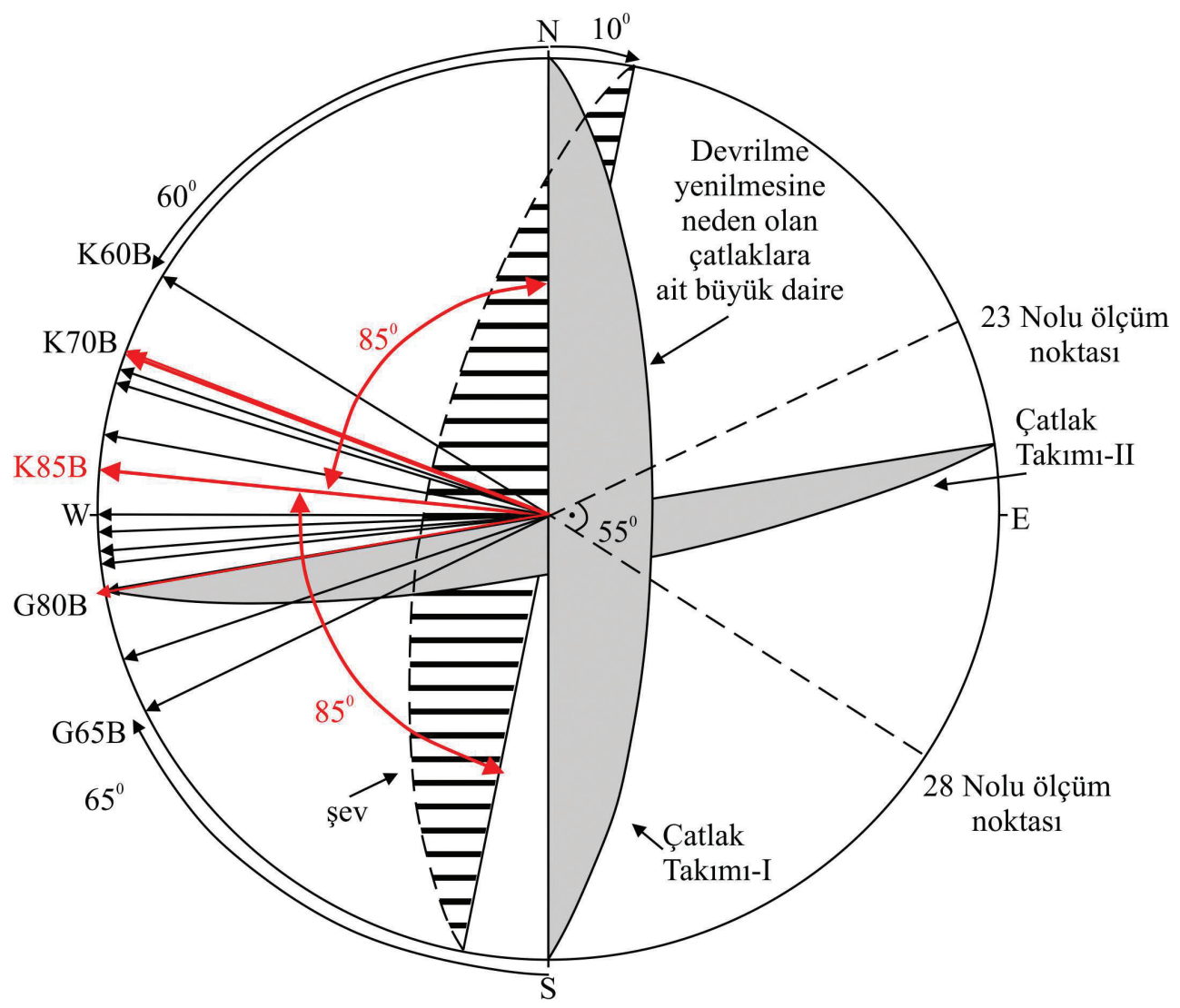

Açıklama

(Altyarım küre)
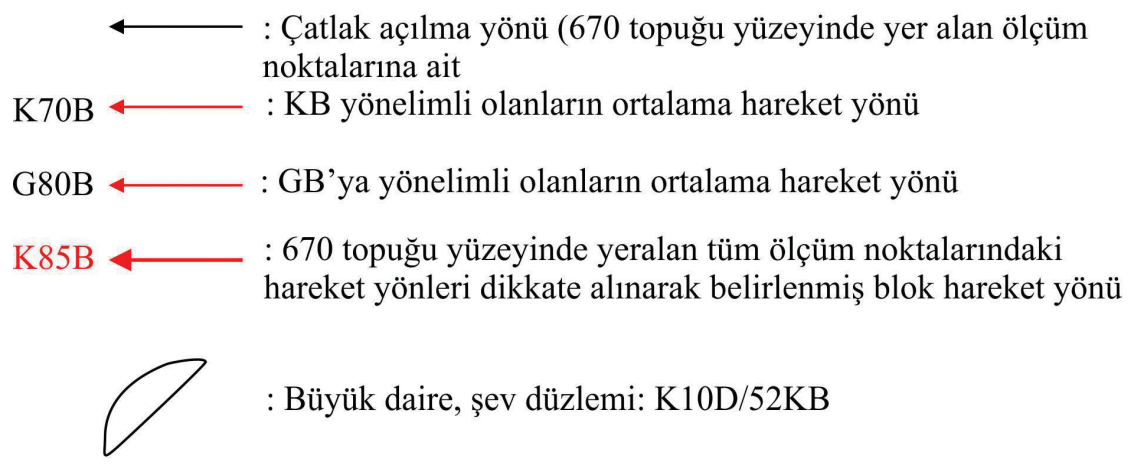

: Büyük daire, şev düzlemi: K10D/52KB

Çatlak takımı-II : K80D/80GD, Çatlak takımı-I: K-G/70D

Şekil 17. Ortalama çatlak hareket yönüyle (K85B) şev düzleminin ve çatlak takımlarının doğrultuları arasındaki ilişkiler.

Figure 17. Relationships between the average direction of movement (N85W) and overall slope, and strikes of the joint sets. 


\section{Çatlaklardaki Açılmalara Ait Hareket Hızlarının Zamana Bağlı Değişimi}

30 Mart 2016 tarihinden itibaren Eynez 670 topuğunda, yaklaşık birbirine dik gelişmiş çatlaklar boyunca gevşeme (açılma) ve hareket belirtileri ortaya çıkmıştır. Eynez kömür sahas1, 670 topuğu yüzeyinde tesis edilmiş deformasyon ölçüm noktalarında, 08 Eylül 2015 ile 02 Haziran 2016 tarihleri arasinda (266 gün) çatlaklardaki açılmalara ait hareket hızlarının zamana bağlı değişimleri incelenmiş ve sonuçları Şekil 18'de sunulmuştur. 30 Mart 2016 ile 02 Haziran 2016 tarihleri arasındaki 64 günlük zaman periyodunda, topuk üzerinde yer alan 11 ölçüm noktasında, dört farklı tarihte hareket miktarlarının zamana bağlı değişimleri (hızları) hesaplanmıştır. 30 Mart 2016 tarihinden 204 gün önce, 08 Eylül 2015 tarihinde de aynı ölçüm noktalarında hareket miktarları ölçülmüştür. Kayda değer hareket hizları (> 6.0 mm/gün) 670 topuğunun tamamından ziyade, topuğun kuzey kesiminde 26, 27 ve 30 nolu ölçüm noktalarının yer aldığı, KDD - GBB yönlü normal fayla Eynez fayı arasında kalan ve yoğun deformasyon izlerinin gözlendiği bölgede saptanmıştır. Diğer fayları kesen KDD - GBB yönlü fay, temel kayacıyla 670 topuğu arasından geçen dokanak fayının (Eynez fayı) doğrultusuna yaklaşık dik uzanmakta ve heyelanlı alanın güney sınırını teşkil etmektedir (Şekil 1 ve 16). Söz konusu bölge, yukarıda sıralanan nedenlere bağl1 olarak, 670 topuğunun diğer kesimlerine göre daha çok örselenmiş, üç tarafi faylarla çevrili hareketli bir alandır. Blok devrilmesi nedeniyle ilk ölçüm noktasının kaybı, 05 Haziran 2016 tarihinde 27nolu ölçüm noktasında gerçekleşmiştir (Şekil $18)$.

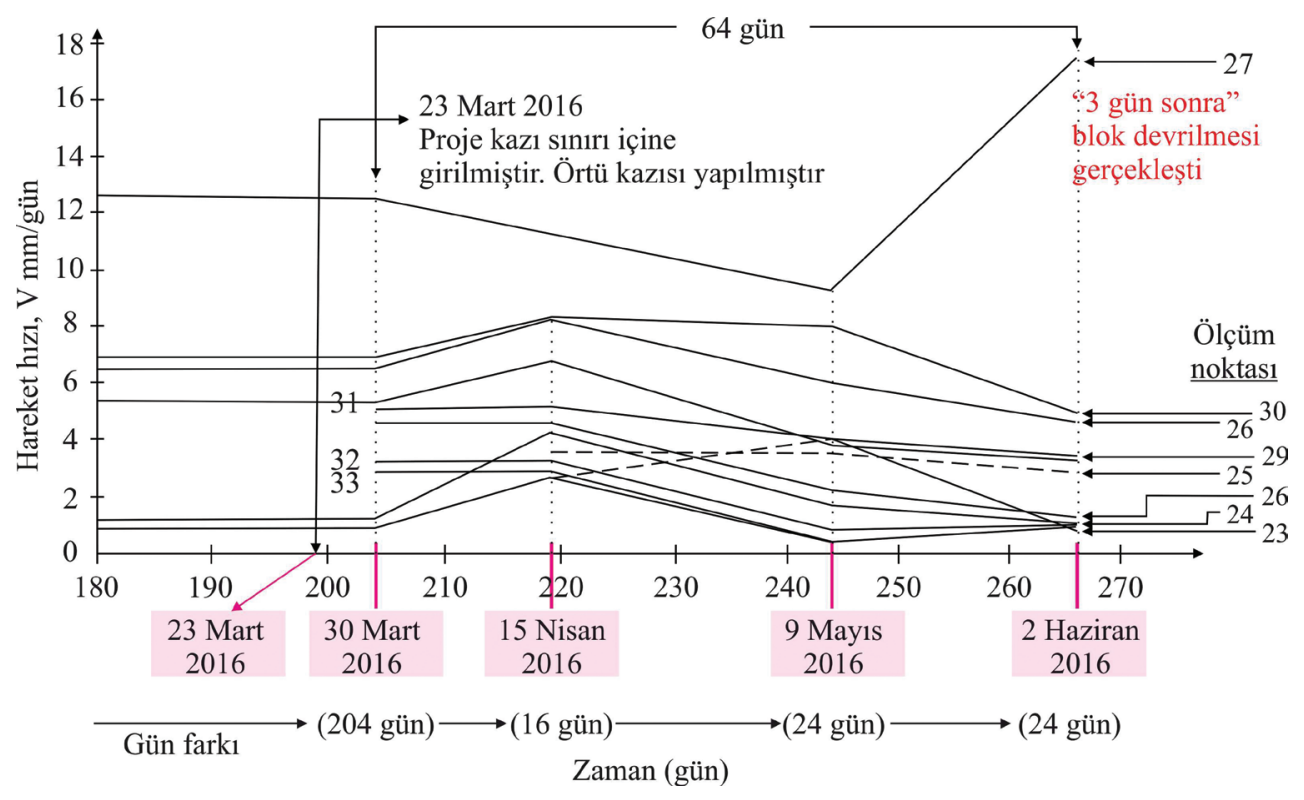

Şekil 18. Eynez kömür sahası 670 topuğu yüzeyinde tesis edilmiş deformasyon ölçüm noktalarının 8 Eylül 2015 ile 02 Haziran 2016 tarihleri arasındaki çatlak açıklığı hareket hızlarının zamana bağlı (gün) değişimi (Ölçümler 268 günlük bir zaman periyodunu kapsamaktadır).

Figure 18. The time - dependent changes of the joint aperture increase rate obtained from the deformation measurement points installed on the surface ground of the 670 pillar from 08 September 2016 to 02 June 2016 (the measurements cover a time period of 268 days). 
27 nolu ölçüm noktası hariç, diğer tüm noktalarda çatlak açıklık artışları 30 Mart 2016 - 15 Nisan 2016 tarihleri arasındaki 15 günlük dönemde meydana geldiği ve 30 nolu ölçüm noktasında söz konusu hız artışının 09 Mayıs 2016 tarihine kadar devam ettiği görülmektedir (Şekil 18). Diğer ölçüm noktalarında hareket hızlarının zamanla azalarak devam ettiği $(<$ $1.0 \mathrm{~mm} /$ gün) anlaşılmaktadır. Hız artışlarının nedeni; 23 Mart 2016 tarihinden itibaren 670 topuğu ile kazı sınırı arasında yer alan ve ikinci emniyet topuğu olarak birakılması önerilen sahada dekapaj çalışmalarının başlatılmasıdır. Böylece, 670 topuğunun batıya bakan şevinde küçük ölçekte blok devrilmeleri tipinde kütle hareketleri de dekapaj çalışmalarına paralel olarak başlamıştır. 670 topuğunun batısında kömür üretimine yönelik olarak yapılan dekapaj çalışmalarına devam edilmesi, şevin önünün açılması anlamını taşımaktadır. Jeolojik bariyer bir kütlenin ortadan kaldırılmasının topuğun stabil kalmasını engelleyeceği önceden yapılan stabilite analizlerinden bilinmektedir. Böylece, söz konusu dekapaj çalışmaları 15 Nisan 2016'da durdurulmuştur.

\section{DEĞERLENDİRMELER}

Kömür damarının yüzeye en yakın olduğu arazi kesiminde, kömürün üretilmesine yönelik örtü kazısı çalışması yapıldığında (Şekil 19), o noktada marn birimi incelecek, kaziya devam edilmesi durumunda ise 670 topuğuna ait şevin stabilitesi bozulacaktır. 670 topuğunun şev tabanında yer alan $15 \mathrm{~m}$ kalınlıktaki marnların bırakılması, şeve topuk olmas1 nedeniyle stabilite açısından önemlidir (Şekil 19). Örtü kazısının başlamasıyla söz konusu alanda yer alan marn kütlesi incelmiş ve oluşan yeni durumda, baskıyla marnlar kırılma eğilimine girmiştir. $\mathrm{Bu}$ durumun sonucu olarak, ikinci emniyet topuğu bırakılmış, proje kazı sınırı 520 m kotuna kadar batıya doğru çekilmiştir. 23 Mart 2016'da proje kazı sınırının dışında, söz konusu alanda örtü kazısının başlatılmasıyla, 670 topuğunun şevinde de bozulmalar başlamıştır. Bu nedenle, 15 Nisan 2016 tarihinde kömürün yüzeye en yakın olduğu alanda dekapaj kazısı durdurulmuştur. Kazının durdurulduğu tarihte, 670 topuğunun güvenliği kritik dengeye (FoS 1.0) erişmiştir. Bu durum, gerilme dağılımının değişimine bağlı olarak 670 topuğunda bir baskı oluşturmuştur. Proje kazı sınırı dışında gerçekleştirilen örtü kazısıyla (670 topuğunuın şev tabanında içe doğru kazı yapılarak), (Şekil 18), batıya doğru şevin kısmen önü açılmış ve 670 topuğunu teşkil eden marn kayaç kütlesinde, yamaç dişına eğimli tabaka eğimleri ve şev doğrultusuna paralel doğrultuda ve yüksek açıda yamaç içine eğimli I-takım çatlakların konumları nedeniyle devrilme türü yenilmeler başlamıştır. 670 topuğu şev üst yüzeyine yakın kesimlerde çatlak açıklıklarının çok kısa sürede, açık ocağa doğru 30-60 cm mertebesine erişmesi, yukarıda bahsedilen baskının sonucu olarak topukta oluşan çekme ve makaslama gerilmelerinin etkisini göstermektedir (Şekil 19).

Eynez fayının deformasyon zonu boyunca, zaman zaman fay gerisinde yer alan gerilme çatlaklarından itibaren faylanmaların olduğu bilinmektedir (aktif fay zonu). Faylanmalar nedeniyle, kayan ve düşen kaya bloklarının 670 topuğunu baskıladığı gözlenmiştir. $\mathrm{Bu}$ bask1, topukta mevcut çatlaklarda açılma ve derinleşmenin yanı sıra, 670 topuğunun şevine yakın kesimlerinde kabarma, şev yükselmesi şeklinde gelişen ve topuğu açı çatlaklı, bloklu yapıya dönüştüren deformasyonlar oluşturmaktadır. 670 topuğu, Eynez fayının oluşumu sırasında gerilmelere maruz kalmış ve marn topuğu ile temel kayacı arasında meydana gelen faylanmayla (dokanak fayı) önceden de 
baskılanmıştır. Baskılarla şevde oluşan gerilmeler 670 topuğunun şevinde ve/veya şevine yakın kesimlerinde açı̆̆a çıkmaktadır. Çatlaklarda açılma gün-gün artma eğilimi göstermektedir.

5 Nisan 2016 tarihinden sonra da 670 topuğunun şevinde yukarıda bahsedilen mekanizmalara bağlı olarak blok devrilme yenilmeleri devam etmiştir. Önceden doğubat1 yönünde 150-175 m yüzey genişliği olan yamuk şekilli 670 topuğu, günümüzde devrilme türü kütle hareketleri nedeniyle aynı yönde yüzey genişliği 25-50 m’e kadar gerilemiştir. Bazı şev kesimlerinde ise, 670 topuğu Eynez fayının aynasına dayanmıştır. Böylece, 670 topuğunda geriye doğru ilerleyen ve dilimler şeklinde meydana gelen devrilme yenilmeleri nedeniyle bir rahatlama (yük kalkması) meydana gelmiştir. Sonuçta, 670 topuğuyla kömür kazısı yapılacak saha (proje kazı sınırı içinde kalan alan) arasındaki mesafe geriye doğru, dilimler şeklinde devam eden devrilme yenilmeleri nedeniyle giderekten açılmış, kütle hareketi nedeniyle devrilen, yuvarlanan kaya bloklarının tehlike oluşturma durumu zamanla ortadan kalkmıştır.

RocTopple bilgisayar yazılımı kullanılarak gerçekleştirilen stabilite analizlerinde, aynı kohezyon ve aynı şev yüksekliği değerlerinde, devrilmeye neden olan çatlakların pik ve rezidüel sürtünme açısı değerlerinin $\phi_{\mathrm{p}}=38^{\circ}$ ve $\phi_{\mathrm{r}}=30^{\circ}$ olması durumunda (I. grup analizler), elde edilen FoS değerlerindeki değişim 0.177 ile 0.207 arasındadır (Çizelge 5). $\mathrm{H}_{\text {şev }}$ sabit, kohezyon ve sürtünme açısının birlikte değişken olması durumunda (2. grup analizler), FoS'da meydana gelen değişim 0.344 ile 0.446 arasında elde edilmiştir.

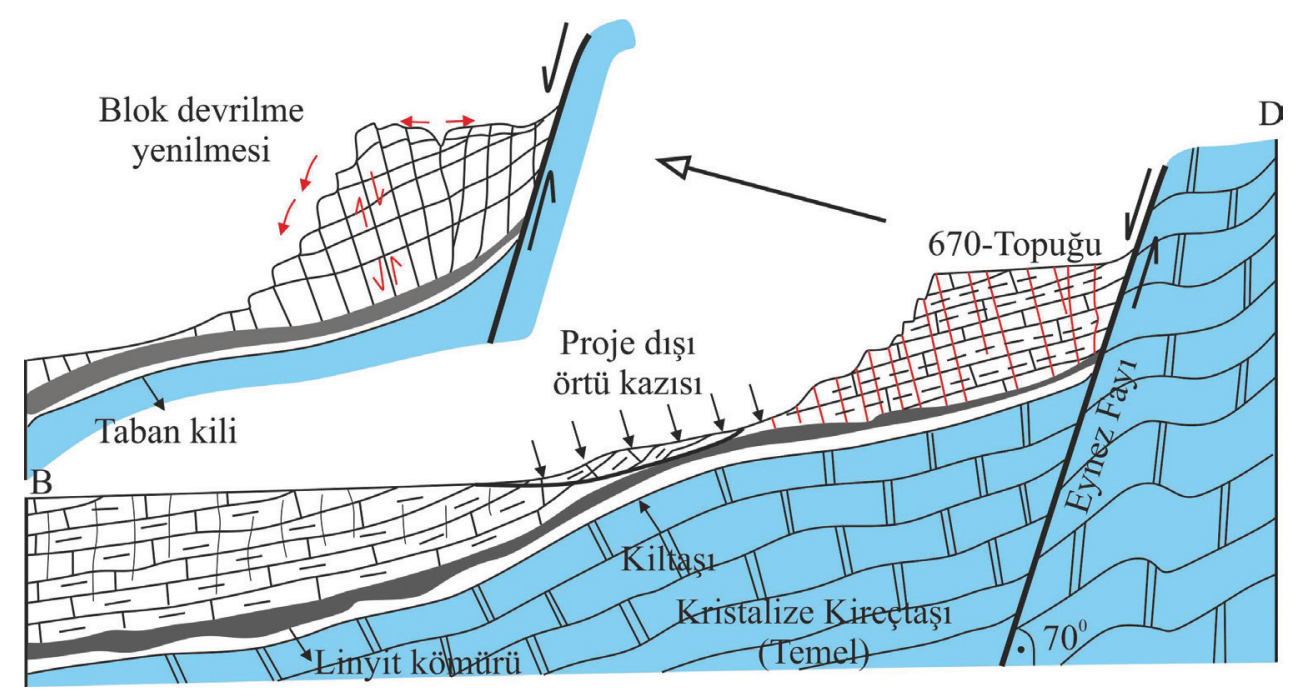

Şekil 19. 670 topuğunda gözlenen devrilme yenilmesinin mekanizması ve oluşan açılmalar.

Figure 19. Mechanisms of the toppling failure observed in 670 pillar and resultant deformations. 
Aynı malzeme özellikleri ve aynı şev geometrileri için Phase $^{2}$ bilgisayar yazılımı kullanılarak da analizler yapılmıştır. I. grup analizlerden elde edilen sonuçların SRF değerlerinde meydana getirdiği değişim 0.09 ile 0.08 arasında olduğu belirlenmiştir. Sonlu elemanlar analizlerindeki küçük değişim aralığı, bu analizlerin deformasyon parametrelerine $\left(\mathrm{E}_{\mathrm{M}}\right.$ ve Poisson oranı) daha bağımlı olduğuna işaret etmektedir. 2. grup analizlerden elde edilen sonuçların SRF değerleri üzerindeki değişimi ise; 0.19 ile 0.24 arasındadır. Her iki bilgisayar yazılımıyla sabit ve değişken parametrelerin güvenlik faktörleri (FoS ve $\mathrm{SRF}$ ) üzerindeki etkileri Çizelge 5 'te toplu olarak sunulmuştur. c ve $\phi$ 'nin birlikte artışının güvenlik faktörü üzerindeki etkisinin, hem $\mathrm{H}_{\text {sev }}$ ve c sabit, $\phi$ değişken hem de $\mathrm{H}_{\text {şev }}$ ve $\phi$ sabit, c değişken olması durumlarında elde edilen güvenlik faktörü değerlerinden çok daha yüksek olduğu anlaşılmaktadır (Çizelge 5).
Deformasyonölçüm noktalarında kaydedilen hareket miktarlarının zonlanmasından elde edilen konturların yönelimleriyle, çatlak takımıII'ye ait süreksizliklerin doğrultuları tam olarak uyum sağlamaktadır (Şekil 17). Çatlak takımıII'ye ait süreksizlikler devrilme yenilmelerinin gözlendiği şevi dikine kesmektedir. Devrilme yenilmesine uğrayan kaya bloklarının şevin aynası boyunca sınırını (blok yan yüzeylerini) kontur yönelimlerinden çatlak takımı-II'ye ait süreksizliklerin belirlediği anlaşılmaktadır. $\mathrm{Bu}$ durum, 670 topuğunun şevinde, devrilmenin tüm şev boyunca değil, devrilmesi muhtemel kaya bloğunun yan duvarlarını/sınırlarını yaklaşık D-B doğrultulu çatlak takımı-II'ye ait süreksizliklerin sınırladığını göstermekte ve devrilmenin tüm şev boyunca değil, dilimler şeklinde geliştiğine işaret etmektedir. Devrilme yenilmesinin meydana geldiği dilim, şevin doğrultusu boyunca bazen $\left(3 \times \mathrm{S}_{2}\right)$, bazen de $(4-$ 5) $\times \mathrm{S}_{2}$ genişliğindedir (Şekil 9).

Çizelge 5. RocTopple ve Phase ${ }^{2}$ bilgisayar yazılımlarılla sabit ve değişken parametrelerin FoS ve SRF değerleri üzerindeki değişim aralıkları.

Table 5. Change intervals on the values of FoS and SRF of the constant and variable parameters with RocTopple and Phase $e^{2}$ softwares.

\begin{tabular}{|c|c|c|c|c|}
\hline Parametreler & Sabit parametre & Değişken parametre & Sabit parametre & Değişken parametre \\
\hline $\mathrm{H}_{\mathrm{sev}}$ & + & - & + & - \\
\hline $\mathrm{c}$ & + & - & - & + \\
\hline$\phi$ & - & + & - & + \\
\hline \multicolumn{5}{|c|}{ Güvenlik faktörü değerlerindeki (FoS ve SRF) değişim aralıkları } \\
\hline $\begin{array}{l}\text { RocTopple } \\
\text { (FoS) }\end{array}$ & \multicolumn{2}{|l|}{$0.177-0.207$} & \multicolumn{2}{|c|}{$0.344(0.927-0.583)-0.446(1.033-0.587)$} \\
\hline $\begin{array}{l}\text { Phase }^{2} \\
\text { (SRF) }\end{array}$ & $0.09-0.08$ & & \multicolumn{2}{|c|}{$0.190(0.84-0.65)-0.240(0.95-0.71)$} \\
\hline
\end{tabular}

Not: Tüm analizlerde şev açısı $52^{\circ}$ alınmıştır. 
Diğer taraftan, dilimin şev gerisine doğru derinliği (dilim kalınlığ 1 ) ise, I. takım süreksizliklerin aralıkları tarafından kontrol edilmekte ve yaygin olarak $1 \mathrm{~S}_{1}$ ve/veya 2 $\mathrm{S}_{1}$ kadardır. Devrilen bloklarda yaygın dilim kalınlığı yaklaşık 1.0 m'dir. Sonuçta devrilmeler, şev boyunca göreceli daha uzun, derinlemesine I. takım süreksizliklerin, süreksizlik aralığı kadar olan ince dilimler şeklinde, şev dışına doğru gelişmektedir. Kaya kütlesi devrildiğinde, şev yüzeyine çarpmalar nedeniyle parçalanmakta ve daha küçük boyutlu kaya parçalarına ayrılmaktadır. Söz konusu dilimlerde, I. takım süreksizliklere ait çatlak açıklığ değerleri de yüksek ise, şevde ilk devrilmeler bu dilimlerde meydana gelmektedir. Çatlak açıklığı ilerleme hızı değerlerinin bir dilimde yüksek olması, o dilim boyunca açılmalar nedeniyle makaslama gerilmelerinin giderekten azalmasina neden olur. Şevde baskının yüksek olmasında diğer bir etken parametre de şev yüksekliğidir. Şev yüksekliği arttıkça, güvenlik faktörünün düştüğü devrilme analizlerinde açıç̧a görülmüştür.

\section{SONUÇLAR}

$\mathrm{Bu}$ çalışmada, Soma-Eynez açık ocak şevinde 70/90 konumlu, şev doğrultusuna paralel, katmanlanmaya yaklaşık dik gelişmiş, yüksek açıda yamaç içine eğimli çatlakların devrilme potansiyeline sahip oldukları hem kinematik hem de nümerik analizlerle belirlenmiştir. 670 topuğunun şevinde prizmatik blok oluşumunu üç takım süreksizlik seti sağlamaktadır. Blokların tavan ve taban düzlemlerini yamaç dışına eğimli marn tabaka düzlemleri oluşturmaktadır. Kaya blokları marn tabaka düzlemleri üzerinde kaymadan, blok devrilmesi oluşturacak şekilde yenilmektedir. Devrilme duraysızlığına neden olan çatlak setine ait geniş aralıklı süreksizlikler arasında kayma yer değiştirmelerinin oluştuğuna ve blokta rotasyona işaret eden $\alpha_{\text {sür }}>(90$ $\left.\alpha_{\text {sev }}\right)+\phi_{\mathrm{r}},\left(\alpha_{\text {sür }}-\phi_{\mathrm{r}}\right)>\left(90-\alpha_{\text {sev }}\right),\left(90-\alpha_{\text {sürek }}\right) \leq$ $\left(\alpha_{\text {sev }}-\phi_{\mathrm{r}}\right)$ eşitlikleri şevde sağlanmıştır. $\mathrm{Bu}$ durumu destekleyen diğer bir veri de $\alpha_{\text {marn }}\left(<\phi_{\text {tabaka }}\right)$ ve $\frac{s_{1}}{S_{2}}=\left(\frac{a}{h}\right)<\tan \left(\alpha_{\text {marn }}\right)$ eşitlikleridir.

$52^{\circ}$ genel şev açısında, 74, 84, 94 ve 110 $\mathrm{m}$ şev yükseklikleri için devrilme analizleri farklı kohezyon ve sürtünme açısı değerleri için gerçekleştirilmiştir. RocTopple programından elde edilen FoS değerlerine göre; $\mathrm{H}_{\text {sev }} \leq 74 \mathrm{~m}$ ve $\mathrm{c}=60 \mathrm{kPa}, \phi_{\mathrm{p}}=38^{\circ}$ olması durumunda ancak şev stabilitesinin kritik dengeye eriştiği belirlenmiştir. Diğer tüm koşullarda FoS değerleri $<1.0$ durumunu yansitmaktadır. Phase ${ }^{2}$ v.7.0 yazılımı ile yapilan analizlerde, $\mathrm{c}=60 \mathrm{kPa}$ ve $\phi_{\mathrm{p}}=38^{\circ}$ olması durumunda, sırasıyla 74, 84 ve $94 \mathrm{~m}$ şev yükseklikleri için SRF değerleri 0.95, 0.91, ve 0.88 olarak elde edilmiştir. c $=40 \mathrm{kPa}$ olduğunda, aynı şev yükseklikleri için SRF değerleri 0.90, 0.86 ve 0.84 gibi değerlere inmektedir $(<1.0)$. $\mathrm{H}_{\text {sev }}=110 \mathrm{~m}$ olmas1 durumunda, c ve $\phi$ 'nin tüm değerleri için $\mathrm{SRF}<0.86$ bulgusu elde edilmektedir. $\mathrm{Bu}$ incelemelerde deprem etkisi (sismik etki), açık işletmede delme-patlatma etkileri ve su seviyesinin olumsuz mevsimsel değişimleri dikkate alınmamıştır. c ve $\phi^{\prime}$ nin birlikte artışının FoS üzerindeki etkisi (2. grup analizler), $\mathrm{H}_{\text {seve }}$, c sabit ve $\phi$ değişken ve $\mathrm{H}_{\text {şev }}, \phi$ sabit, c değişken olması durumlarında elde edilen FoS değerlerinden çok daha yüksek olduğu belirlenmiştir. Şev yüksekliği ve kohezyon sabit, $\phi$ açıs $30^{\circ}$ ve $38^{\circ}$ için RocTopple yazılımından elde edilen FoS değerleri arasındaki minimum ve maksimum fark sirasiyla 0.177 ve 0.207 olarak belirlenmiştir. $\phi_{\mathrm{r}}=30^{\circ}$ durumunda SRF değerleri, RocTopple yazılımından elde edilen FoS değerlerinden daha büyük elde edilmiştir. Buna karşın, $\Phi_{\mathrm{p}}=38^{\circ}$ için ilginç bir şekilde FoS $>$ SRF durumu oluşmuştur. Bunun nedeni, $\phi$ açıs1 artışına RocTopple yazılımının Phase ${ }^{2}$ den çok 
daha hassas olmasıdır. Derin şevler için gerek SRF $>$ FoS gerekse de FoS $>$ SRF durumlarında, her iki güvenlik faktörü arasındaki farkın stabiliteyi doğrudan etkileyecek düzeyde bir büyüklüğe sahip olmadiğ 1 belirlenmiştir ( $\leq$ $0.123)$. Bu fark ( $\leq 0.123)$ açık ocak şevlerinde, patlatma etkilerinin güvenlik faktörü üzerine yaptığı etkiden de düşük bir etki düzeyine karş11ık gelmektedir.

670 topuğunun batıya bakan şevinde meydana gelen devrilme yenilmeleri nedeniyle gerek örtü gerekse de kömür çıkarımına yönelik kazıların yapılabilmesi güvenlik açısından tehlike oluşturmuştur. Bunun giderilebilmesi için, proje kazı sınırı tehlikeli bölgenin batısına, $520 \mathrm{~m}$ kotlarına çekilmiştir. Bu sınırın belirlenmesinde, devrilen kaya parçalarının maksimum yuvarlanma mesafeleri dikkate alınmıştır. Proje kazı sınırı; farklı şev yüksekliklerinde tehlikeli alan için $135 \mathrm{~m}$ ile $200 \mathrm{~m}$ arasında değerler aldığ 1 belirlenmiştir.

670 topuğunun üzerinde yeralan 26, 27 ve 30 nolu deformasyon ölçüm noktalarında maksimum çatlak açıklığ $\geq 38.53 \mathrm{~cm}$ ve maksimum hız değerleri $v \geq 6.05 \mathrm{~mm} /$ gün olarak saptanmıştır. Bu hareketler 30 Mart 2016 ile 02 Haziran 2016 tarihleri arasındaki 64 günlük zaman aralığında, proje kazı sınırının dışında yapılan örtü kazıları nedeniyle meydana gelmiştir. İlk devrilme yenilmesi 05 Haziran 2016 tarihinde 27 nolu ölçüm noktasında (toplam hareket miktarı: $60.53 \mathrm{~cm}$, hareketin hızı:13 mm/gün) meydana gelmiştir. Devrilme yenilmelerinin ilk gözlendiği alan, 670 topuğunun kuzey ucunda, $\mathrm{H}_{\text {sev }}>100$ $\mathrm{m}$ olduğu, kuzeyi ve batısı faylarla sınırl1, göreceli yüksek örselenmeye maruz kalmış bir alandır. Devrilme yenilmelerinin gözlendiği bu ilk dilim güneyden de $>55 \mathrm{~cm}$ süreksizlik açıklık konturuyla sınırlıdır. 670 topuğu şevinde gözlenen devrilme yenilmelerinin, şev yüzeyinden şev gerisine doğru (Eynez fayına doğru) ilerleyen kütle hareketleri olduğu ortaya çıkmıştır.

KDD - GBB gidişli faylı dere yatağı, Eynez fayını dikine kesmekte ve çatlak sularını taban kayacından açık ocak şevlerine doğru boşaltmaktadır. Eynez fay zonunun diğer kesimlerine göre bu faylı dere yatağı boyunca kütle hareketleri meydana gelmiştir. $\mathrm{Bu}$ zon boyunca kütle hareketlerinin oluşmasında "taban kili+su+Eynez fayının deformasyon zonu" birlikte rol almıştır. Bu nedenle, 26, 27 ve 30 nolu deformasyon ölçüm noktalarının bu faylı dere yatağına en yakın ölçüm noktaları olduğu da unutulmamalıdır.

\section{KAYNAKLAR}

Anon 1979a. Classification of rocks and soils for engineering geological mapping, Part - 1, Rock and soil materials. Bulletin of Engineering Geology and the Environment, 19, $364-371$.

Bandis S. C., Lumsden A. C., Barton N. R., 1983. Fundamentals of rock joint deformation. International Journal of Rock Mechanics Mining Sciences and Geomechanics Abstracts, 20, 249268.

Barton, N.R., 1972. A model study of rock-joint deformation. International Journal of Rock Mechanics and Mining Sciences, 9, 579-602.

Brideau, M. A. Stead, D., 2009. Controls on block toppling using a three-dimensional dinstinct element approach. Rock Mechanics and Rock Engineering, 43, $241-260$.

Bobet, A., 1999. Analytical solutions for toppling failure (Technical note). International Journal of Rock Mechanics and Mining Sciences, 36, $971-980$.

Goodman, R. E., 1976. Methods of Geological Engineering in Discontinuous Rocks, West Publishing Co. St Paul. MM, 472 p. 
Goodman, R. E., Bray, J. W., 1976. Toppling of rock slopes. Proceedings of the specialty conference on rock engineering for foundations and slopes, pp. 201-234.

Hoek, E., Bray, J., 1974. Rock Slope Engineering, Institution of Mining and Metallurgy, Printed in Great Britain by Unvin Brothers Lim., London, 309 p.

Hoek, E., Diederichs, M. S., 2006. Empirical estimation of rock mass modulus. International Journal of Rock Mechanics and Mining Sciences, $43,203-215$.

ISRM (International Society for Rock Mechanics), 2007. The complete ISRM suggested methods for rock characterization, testing and monitoring: Eds: Ulusay, R. Hudson, J.A., 678 p.

Itasca, 2000. UDEC (Universal Dintinct Element Code) Version 3.0. User's Manual.

Kincal, C., Koca, M. Y., 2009. A proposed method for drawing the great circle representing dip angle and strike changes. Environmental and Engineering Geoscience, Vol. XV, 3. August, $145-185$.

Koca, M. Y., Kincal, C., 2004. Abondoned stone quarries in and around the İzmir city centre and their geo-environmental Impacts-Turkey. Engineering Geology, 75, 49 - 67.

Marinos, P., Hoek, E., 2001. Estimating the geotechnical properties of heterogeneous rock masses such as flysch. Bulletin Engineering Geology and Environment, 60, 85-92.

Matterson, G. D., 1988. The collection and use of field discontinuity data in rock design. Quarterly Journal of Engineering Geology and Hydrogeology, 22, $19-30$.
Nassir M., Settari A., Wan R., 2009. Joint stiffness and deformation behaviour of discontinuous rock. Journal of Canadian Petroleum Technology, 49 (9), 78-86.

Norrish, N. I., Wyllie, D. C., 1996. Rock slope stability analysis. In: Special Report, 247: Landslides: Investigation and Mitigation, A. K. Turner and R. L. Schuster (eds.), TRB, National Research Council, Washington D. C., pp. $391-425$.

Rocscience Inc., 2004. Rocfall v.4.0.3.9-Statistical analysis of rockfalls. Toronto, Ontario, Canada.

Rocscience Inc., 2020. RocTopple v2.002, Toppling failure analysis. Toronto, Ontario, Canada.

Rocscience Inc., 2008 Phase2 v7.0, Finite Element Analysis for Excavations and Slopes; Toronto, Ontario, Canada.

Son, B. K., Lee, Y. K., Lee, C. I., 2004. Elasto-plastic simulation of direct shear test on rough rock joints. International Journal of Rock Mechanics and Mining Sciences, Proceedings of the ISRM Sinorock 2004 symp., 41 (1)supplement 1, pp. 354-359.

Wyllie, D. C. \& Mah, C. W., 2004. Rock Slope Engineering: $4^{\text {th }}$ Edition, Spon Press, London and New York, $432 \mathrm{p}$.

Wyllie, D. C., 1989. Toppling rock slope failures, examples of analysis and stabilization. Rock Mechanics, 13, $89-98$.

Yoon, W. S., Jeong, U. J., Kim, J. H., 2002. Kinematic analyses for sliding failure of multi-faced rock slopes. Engineering Geology, 67, 51 - 61 . 